\title{
Identifying optimal renovation schedules for building portfolios: application in a social housing context under multi-year funding constraints
}

\author{
Authors: \\ Marie-Lise Pannier ${ }^{1,2}$, Thomas Recht ${ }^{1}$, Maxime Robillart ${ }^{3}$, Patrick Schalbart ${ }^{4}$, Bruno Peuportier ${ }^{4}$, \\ Laurent Mora ${ }^{1}$ \\ ${ }^{1}$ Univ. Bordeaux, 12M Bordeaux, 351 cours de la Libération, F-33400 Talence, France \\ ${ }^{2}$ Univ Angers, LARIS, SFR MATHSTIC, F-49000 Angers, France \\ ${ }^{3}$ Kocliko - 74 cours Aristide Briand, 33000 Bordeaux \\ ${ }^{4}$ MINES ParisTech, PSL Research University, CES - Centre d'efficacité énergétique des systèmes, 60 \\ Bd St Michel, 75006 Paris, France
}

\section{Highlights, Abstract, Keywords}

Highlights

- A tool was developed to help real estate owners plan refurbishment

- The tool identifies priorities in terms of actions and buildings to be retrofitted

- It combines dynamic building energy simulations and multi-objective optimisation

- It was applied to a social housing stock with a multi-year budget constraint

- Priorities are set based on the identified optimal renovation schedules

\begin{abstract}
Identifying optimal refurbishment strategies for a building stock is a challenging task. Numerous energy efficiency measures can be undertaken for each building. In addition, under financial constraints, real estate owners have to decide in which buildings and renovation actions to invest first, as well as how to plan renovations over time. A methodology combining multi-objective optimisation (MOO) with dynamic building energy simulation is proposed to help building stock managers to set their priorities. The MOO is based on the NSGA-II algorithm: a first chromosome represents the possible buildings and the actions to invest in, while a second chromosome corresponds to the temporal sequencing of these retrofit choices. Finally, optimal refurbishment schedules can be identified. The methodology is applied to multi-dwelling units of a portfolio property owner in Greater Paris Area. Refurbishment schedules, minimising investment cost and energy consumption, and meeting yearly budget constraints, were analysed. Among optimal schedules, actions that are frequently selected on a building during the first few years of renovation are identified as priorities. The developed methodology, implemented in a tool, thus provides a first level of decision aid.
\end{abstract}




\section{Keywords}

Building stock; Refurbishment; Dynamic building energy simulation; Planning; Energy-cost optimisation

\section{Acronyms $^{1}$}

\section{Introduction}

Buildings refurbishment is on the agenda in many countries in order to face todays' global challenges. Due to the low rate of new construction, the potential of building retrofitting is significant not only from an environmental point of view to save energy resources [1] and to mitigate climate change [2], but also from a social perspective to reduce energy poverty [3]. However, efficient building refurbishment may be difficult to achieve. Many combinations of refurbishment actions can be identified for the same building and the objectives may be conflicting [4]. Choosing of the most efficient combination is thus complex and difficult to generalise to other buildings. On a wider scale, i.e. at a district or portfolio scale, the savings potential is higher but the number of feasible renovation combinations increases as efficient combinations have to be chosen for each building. Furthermore, given budgetary constraints, renovation priorities should be given to some buildings or some actions, and renovation works should be planned over time. Therefore, three important questions need to be answered when refurbishing a group of buildings: "which set of renovation actions should be performed?", "which building should be refurbished first?" and "when should renovations be performed?" [5]. Several tools have already been developed to solve such complex optimisation problem in a context of neighbourhoods, districts, portfolios or cities refurbishment [613], but most of them fail to answer to all of these questions. In this work, a tool associating dynamic

\footnotetext{
${ }^{1}$ Acronyms : AHP: Analytic Hierarchy Process; B: Large apartment block; CAPEX: CAPital EXpenditure; D1: District 1; D2: District 2; DHW: Domestic Hot Water; DBES: Dynamic Building Energy Simulation; E-W: East-West Orientation; GA: Genetic Algorithm; GHG: Greenhouse Gases; LCC: Life Cycle Cost; MACBETH: Measuring Attractiveness by a Categorical Based Evaluation Technique; MCDM: MultiCriteria Decision Making; MILP: Mixed-Integer Linear Programing; MOO: Multi-Objective Optimisation; N-S: North-South Orientation; NPV: Net Present Value; OPEX: OPerating EXpenditure; PSO: Particle Swarm Optimisation; SA: Sensitivity Analysis; T: Tower; UA: Uncertainty Analysis.
} 
building energy simulation, cost assessment and multi-objective optimisation was developed to answer the "which action", "which building" and "which year" questions.

\subsection{Methods for building performance improvement}

Choosing the most appropriate set of actions to improve the performance of buildings is a complex task. Many actions can be performed on the envelope and systems. In addition, the performance can be perceived differently by each building actor (designer, investor, owner, tenant...) and many criteria and constraints should be taken into account: e.g. improving energy efficiency, complying with budget and standards, avoiding discomfort, increasing building value, improving the quality of life ... In order to find the most appropriate set of actions in a given context, multi-objective optimisation (MOO) and multi-criteria decision making (MCDM) have been used in new construction and renovation contexts [5,14]. In MOO, a set of objectives functions (i.e. formulations of the performance criteria) are jointly minimised. Following the principle of Pareto-optimality, each objective is as important as the others. The solutions to the optimisation problem are then trade-offs between the potentially conflicting objectives. Given the set of optimal solutions, one solution can be chosen a posteriori, for instance using MCDM methods [15]. In MCDM, a solution is chosen, among a set of predefined solutions, based on the decision-makers' preferences and existing uncertainties and constraints. Weighting methods are often employed to give priority to criteria that best reflect the decision-makers' preferences.

Optimisation methods have been widely used over the past two decades to improve the performance of buildings as shown by the numerous review articles on this topic $[4,14-18]$. They were applied to new or existing buildings $[4,14]$ with the aim of reducing costs and energy consumption, as well as in some case improving comfort and reducing environmental impacts $[4,14,17,19]$. Among the existing MOO algorithms, genetic algorithms (GA) are by far the most popular [14-16]. In GAs, a population evolves towards optimum solutions following the principle of natural selection [17]. Several reasons explain the popularity of GAs: their efficiency in converging 
toward the theoretical Pareto front; their ability to deal with continuous and discrete variables and to handle non-linear or discontinuous problem without converging to a local minima; the possibility to run parallel simulations of each population member $[4,18]$.

MCDM has been used in new construction for the design of building components [20], as well as in existing buildings for renovation purposes [5,21]. Taillandier et al. [22] studied a two-step approach with a multi-criteria analysis to find the best renovation actions for houses based on the owner's preferences, building characteristics, and experts knowledge of technical feasibility. In a refurbishment context, the criteria included in the decision making process are related to social, environmental and economic sustainability; environmental quality criteria remaining the most often represented in decision support tools [5].

A large majority of studies focussed on MOO or MCDM for one building, while assessment at the building stock level was less addressed $[10,9,23,24]$. However, dealing with larger spatial scale is relevant to help municipalities or portfolio property owners to set renovation priorities.

\subsection{Modelling and assessing the performances of building stocks}

Over the past decade, an increasing number of studies have investigated the performance at the building stock level. According to Peri et al. [25] and Österbring et al. [23], these studies mainly aimed at estimating the current energy consumption of an existing building stock or the potential savings (economic or energetic) achievable through energy retrofit measures. This is useful for planning energy strategies and to predicting future energy demand, as well as for setting priorities in the development of the stock and in the refurbishment of existing buildings. Environmental impacts of a building stock retrofit have also been evaluated, with a special attention to the reduction of greenhouse gases (GHG) emissions $[8,12,26]$.

Building stock can be modelled using bottom-up or top-down approaches $[27,28]$. In the first approach, the energy consumption of each building, or of some representative buildings, is assessed using statistical or engineering (physics-based) methods. Then results are extrapolated to get the 
total energy consumption of the stock. In the top-down approach, aggregated econometric or technological data (e.g. historical consumption data for a city or a country) are used to obtain the building stock consumption. Building physics based bottom-up approaches are the most common approaches to estimate the energy-saving potential of existing building stocks according to Brøgger and Wittchen [29]. Such approaches seem suitable to help building stock managers to decide which actions to perform, which building to refurbish and how to plan renovation work over time.

\subsection{Setting priorities when refurbishing building stocks}

Some research articles have focussed on setting refurbishment priorities at the building stock level. A set of 19 research articles were identified; they aimed at answering to, at least, one of the "which action", "which building" and "which year" questions. These papers are referenced in the Table 1. Problems formulation, methods used and questions answered in these articles are dealt with in the next paragraphs. 
Table 1: Scope of the articles related to building stock refurbishment (chronological order)

\begin{tabular}{|c|c|c|c|c|c|c|c|c|}
\hline \multirow[t]{2}{*}{ Article } & \multirow[t]{2}{*}{ Building stock } & \multicolumn{4}{|c|}{ Questions answered } & \multirow[t]{2}{*}{ Method } & \multirow{2}{*}{$\begin{array}{l}\text { Objectives or } \\
\text { Criteria }\end{array}$} & \multirow[t]{2}{*}{ Constraints } \\
\hline & & 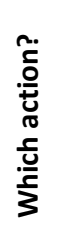 & 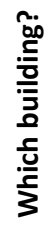 & 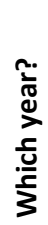 & 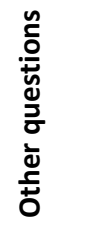 & & & \\
\hline $\begin{array}{l}\text { Bana e } \\
\text { Costa and } \\
\text { Oliveira, } \\
2002[30]\end{array}$ & $\begin{array}{l}\text { Housing stock of } \\
\text { the municipality of } \\
\text { Lisbon }\end{array}$ & $x$ & $\mathbf{x}$ & & & $\begin{array}{l}\text { MCDM: } \\
\text { MACBETH }\end{array}$ & $\begin{array}{l}\text { Technical, } \\
\text { and } \\
\text { concerns }\end{array}$ & Total budget \\
\hline $\begin{array}{l}\text { Keirstead } \\
\text { and } \\
\text { Calderon, } \\
2012[31]\end{array}$ & $\begin{array}{l}\text { City and districts of } \\
\text { Newcastle }\end{array}$ & $x$ & & $\mathbf{x}$ & 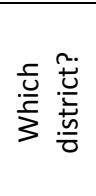 & MILP & $\begin{array}{l}\text { Total cost of } \\
\text { energy system } \\
\text { (investment and } \\
\text { operation) }\end{array}$ & $\begin{array}{l}\text { Compliance with } \\
\text { carbon budget } \\
\text { Appropriated } \\
\text { retrofit } \\
\text { measures }\end{array}$ \\
\hline $\begin{array}{l}\text { Jennings et } \\
\text { al., } 2014 \\
{[32]}\end{array}$ & $\begin{array}{l}\text { Residential } \\
\text { buildings in London }\end{array}$ & $x$ & & $x$ & 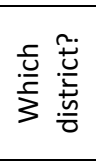 & MILP & $\begin{array}{l}\text { Sum of discounted } \\
\text { operational and } \\
\text { capital costs, less } \\
\text { potential incomes }\end{array}$ & $\begin{array}{l}\text { GHG emission } \\
\text { (in one scenario) }\end{array}$ \\
\hline $\begin{array}{lr}\text { Mauro } r & \text { et } \\
\text { al., } & 2015 \\
{[33]} & \end{array}$ & $\begin{array}{l}\text { Office buildings in } \\
\text { South Italy }\end{array}$ & $\mathbf{x}$ & & & & $\begin{array}{l}\text { SA to identify } \\
\text { to cost- } \\
\text { effective } \\
\text { retrofit } \\
\text { packages }\end{array}$ & $\begin{array}{l}\text { Primary energy } \\
\text { consumption, } \\
\text { Life cycle cost } \\
\text { (LCC), } \\
\text { Thermal comfort }\end{array}$ & \\
\hline $\begin{array}{l}\mathrm{He} \text { et al., } \\
2015[6]\end{array}$ & $\begin{array}{l}\text { Housing in the } \\
\text { North East of } \\
\text { England }\end{array}$ & $x$ & & & & $\begin{array}{l}\text { MOO: } \\
\text { NSGA-II }\end{array}$ & $\begin{array}{l}\text { Energy demand, } \\
\text { Investment cost }\end{array}$ & \\
\hline $\begin{array}{l}\text { Wu et al., } \\
2016 \text { [7] }\end{array}$ & $\begin{array}{l}1 \text { commercial } \\
\text { building }+1 \text { office } \\
\text { building }\end{array}$ & 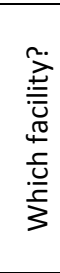 & $x$ & $\mathbf{x}$ & & $\begin{array}{l}\text { MOO: } \\
\text { Optimal } \\
\text { control on the } \\
\text { weighted-sum } \\
\text { the } \\
\text { objectives }\end{array}$ & $\begin{array}{l}\text { Energy savings, } \\
\text { NPV }\end{array}$ & $\begin{array}{l}\text { Energy saving } \\
\text { target } \\
\text { Investment } \\
\text { budget } \\
\text { Number of } \\
\text { retrofitted } \\
\text { facilities }\end{array}$ \\
\hline $\begin{array}{l}\text { Taillandier } \\
\text { et al., } 2017 \\
\text { [34] }\end{array}$ & $\begin{array}{l}\text { Buildings of a } \\
\text { French real estate } \\
\text { property owner }\end{array}$ & $x$ & $\mathbf{x}$ & $\mathbf{x}$ & & $\begin{array}{l}\text { MOO: particle } \\
\text { swarm } \\
\text { optimisation }\end{array}$ & $\begin{array}{l}\text { Score of the } \\
\text { criteria of a } \\
\text { knapsack problem: } \\
\text { regulatory } \\
\text { compliance, asset } \\
\begin{array}{l}\text { value, client } \\
\text { satisfaction }\end{array}\end{array}$ & Annual budget \\
\hline $\begin{array}{l}\text { Wu et al., } \\
2017 \text { [8] }\end{array}$ & $\begin{array}{l}\text { Residential } \\
\text { buildings of a Swiss } \\
\text { village }\end{array}$ & $\mathbf{x}$ & $\mathbf{x}$ & & & $\begin{array}{l}\text { MOO: } \quad \varepsilon- \\
\text { constrained } \\
\text { MILP }\end{array}$ & $\begin{array}{l}\text { Annualised } \\
\text { investment cost, } \\
\text { GHG emission }\end{array}$ & $\begin{array}{l}\text { Historical } \\
\text { protection }\end{array}$ \\
\hline $\begin{array}{l}\text { Luddeni et } \\
\text { al., } 2018 \\
{[11]}\end{array}$ & $\begin{array}{l}\text { Existing Italian } \\
\text { office building stock }\end{array}$ & $x$ & $\mathbf{x}$ & & & MOO: NSGA-II & $\begin{array}{l}\text { LCC, } \\
\text { Energy savings }\end{array}$ & \\
\hline $\begin{array}{l}\text { Soutullo et } \\
\text { al., } 2018 \\
{[35]}\end{array}$ & Dwellings in Madrid & $x$ & & & & $\begin{array}{l}\text { Local } \\
\text { sensitivity } \\
\text { analysis: One } \\
\text { refurbishment } \\
\text { action at A } \\
\text { Time }\end{array}$ & Energy savings & \\
\hline
\end{tabular}




\begin{tabular}{|c|c|c|c|c|c|c|c|c|}
\hline \multirow[t]{2}{*}{ Article } & \multirow[t]{2}{*}{ Building stock } & \multicolumn{4}{|c|}{ Questions answered } & \multirow[t]{2}{*}{ Method } & \multirow{2}{*}{$\begin{array}{l}\text { Objectives or } \\
\text { Criteria }\end{array}$} & \multirow[t]{2}{*}{ Constraints } \\
\hline & & 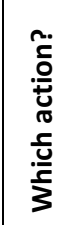 & 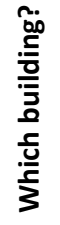 & 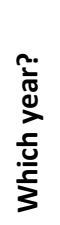 & 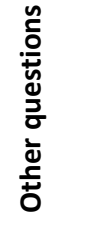 & & & \\
\hline $\begin{array}{l}\text { Carbonari et } \\
\text { al., } 2019 \\
{[36]}\end{array}$ & Schools near Milan & & $x$ & & & MCDM : AHP & $\begin{array}{l}\text { Level of } \\
\text { compliance } \\
\text { regarding } \\
\text { accessibility, } \\
\text { energy efficiency } \\
\text { and acoustics }\end{array}$ & \\
\hline $\begin{array}{l}\text { Gabrielli et } \\
\text { Ruggeri } \\
2019 \text { [9] }\end{array}$ & $\begin{array}{l}\text { Portfolio of public } \\
\text { buildings of the } \\
\text { University } \\
\text { Ferrara }\end{array}$ & $x$ & $\mathbf{x}$ & $x$ & & $\begin{array}{l}\text { MOO: } \\
\text { Multi } \\
\text { attribute } \\
\text { linear } \\
\text { programming }\end{array}$ & $\begin{array}{l}\text { Net savings, } \\
\mathrm{CO}_{2} \text { savings, } \\
\text { Internal comfort, } \\
\text { Restoration } \\
\text { aspects }\end{array}$ & Limited budget \\
\hline $\begin{array}{l}\text { Garcia- } \\
\text { Fuentes et } \\
\text { al., } \quad 2019 \\
{[37]}\end{array}$ & $\begin{array}{l}\text { Buildings of a } \\
\text { residential } \\
\text { neighbourhood in } \\
\text { Vallalodid }\end{array}$ & $\mathbf{x}$ & $x$ & & & $\begin{array}{l}\text { MCDM: } \\
\text { weighing for } \\
\text { benefits and } \\
\text { for cost } \\
\text { criteria } \\
\text { Find Pareto } \\
\text { optimality } \\
\text { between costs } \\
\text { and benefits }\end{array}$ & $\begin{array}{l}\text { GHG emissions, } \\
\text { Energy } \\
\text { consumption and } \\
\text { payback time, } \\
\text { Investment, LCC } \\
\text { and payback } \\
\text { period, } \\
\text { Comfort, } \\
\text { Use of renewables }\end{array}$ & $\begin{array}{l}\text { Maximal } \\
\text { investment, } \\
\text { Economic } \\
\text { payback period, } \\
\text { Energy payback } \\
\text { time }\end{array}$ \\
\hline $\begin{array}{l}\text { He et al., } \\
2019 \text { [10] }\end{array}$ & $\begin{array}{l}\text { Buildings of a non- } \\
\text { governmental } \\
\text { organisation in the } \\
\text { state of Delaware }\end{array}$ & $\mathbf{x}$ & $\mathbf{x}$ & & & $\begin{array}{l}\text { MOO: } \\
\text { combination } \\
\text { of particle } \\
\text { swarm } \\
\text { optimisation } \\
\text { and GA }\end{array}$ & $\begin{array}{l}\mathrm{NPV}, \quad \text { Payback } \\
\text { period, } \\
\text { Energy savings, } \\
\text { Emission reduction } \\
\text { of } \mathrm{CO}_{2} ; \mathrm{SO}_{2} ; \mathrm{NO}_{x}\end{array}$ & $\begin{array}{l}\text { Financing } \\
\text { budgetary } \\
\text { restraints }\end{array}$ \\
\hline $\begin{array}{lr}\text { Nägeli } & \text { et } \\
\text { al., } & 2019 \\
{[38]} & \end{array}$ & $\begin{array}{l}\text { Multifamily housing } \\
\text { stock of the } \\
\text { municipal property } \\
\text { owner for the city } \\
\text { of Gothenburg }\end{array}$ & 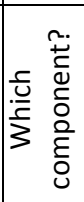 & & $x$ & & $\begin{array}{l}\text { MARS method } \\
\text { [39] }\end{array}$ & Lifecycle costs & \\
\hline $\begin{array}{l}\text { Österbring } \\
\text { et al., } 2019 \\
{[23]}\end{array}$ & $\begin{array}{l}\text { Multifamily housing } \\
\text { stock of the } \\
\text { municipal property } \\
\text { owner for the city } \\
\text { of Gothenburg }\end{array}$ & & $\mathbf{x}$ & & 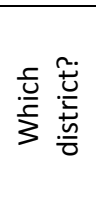 & $\begin{array}{l}\text { Cost- } \\
\text { effectiveness } \\
\text { of one } \\
\text { renovation } \\
\text { package }\end{array}$ & $\begin{array}{l}\text { Equivalent annual } \\
\text { cost } \\
\text { Energy savings }\end{array}$ & \\
\hline $\begin{array}{lr}\text { Pistore } r & \text { et } \\
\text { al., } & 2019 \\
{[24]} & \end{array}$ & $\begin{array}{l}\text { Public building } \\
\text { stock of schools in } \\
\text { Treviso }\end{array}$ & $\mathbf{x}$ & $\mathbf{x}$ & & & $\begin{array}{l}\text { Data mining: } \\
\text { Wrapper } \\
\text { feature } \\
\text { selection, } \\
\text { Random } \\
\text { forest and } \\
\text { clustering }\end{array}$ & $\begin{array}{l}\text { Energy } \\
\text { consumption }\end{array}$ & \\
\hline $\begin{array}{l}\text { Murray et } \\
\text { al., } 2020 \\
{[12]}\end{array}$ & Swiss building stock & $x$ & $x$ & & & $\begin{array}{l}\text { MOO: } \varepsilon- \\
\text { constrained } \\
\text { MILP }\end{array}$ & $\begin{array}{l}\text { LCC, } \\
\text { Life cycle GHG } \\
\text { emissions }\end{array}$ & \\
\hline $\begin{array}{lr}\text { Rogeau } & \text { et } \\
\text { al, } \quad 2020 & \\
{[13]} & \end{array}$ & $\begin{array}{l}\text { Housing in a } \\
\text { suburban } \\
\text { neighbourhood in } \\
\text { the Rhône } \\
\text { department }\end{array}$ & $\mathbf{x}$ & $x$ & & & $\begin{array}{l}\text { Variant of the } \\
\text { knapsack } \\
\text { problem }\end{array}$ & NPV & \\
\hline
\end{tabular}




\subsubsection{Building stock modelling}

Building stocks studied in previous articles are various in terms of size and type. The smallest building stocks consisted in two buildings [7,36], while some studies considered thousands of buildings $[13,23,31,32,38]$. Often 5 to 50 different buildings were considered $[8-11,24,34,35,37]$. As highlighted in Table 1, building stocks belong to one owner (e.g. private real estate property owner or municipal owner) or to multiple owners, as in Murray et al. [12] and Rogeau et al. [13] where statistical data for countries were used to model the building stock. Buildings were grouped in one district or one city, or they were spread over a large territory such as a region or a country. In most cases, buildings in a stock had the same use, and several types of stock were studied: housing stocks $[6,8,13,23,30,32,35,37,38]$, stocks of schools or university buildings $[9,24,36]$, or stocks of offices or commercial buildings $[10,11,33,34]$.

Regarding the stock modelling, a bottom-up approach was adopted in all papers of Table 1. For small stocks, the engineering method was chosen and all buildings were fully described based on real buildings $[7,10,30,34,36,37]$. For larger stocks, when data was available, a set of representative buildings was sometimes selected using clustering methods or expert knowledge. Categories of buildings were then built according to the year of construction, building size, orientation, use, constructive technique or climate zones. Only these representative buildings were fully described based on existing buildings $[6,8,9,11,24,35]$. Optimal refurbishment scenarios were then identified for each representative building and in some cases, the savings potential were scaled up to get the savings potential of the entire stock $[6,8,9,11]$. Statistical bottom-up methods were also applied in order to model cities or countries $[12,13,23,31-33,38]$. In this case, national databases, created from surveys, were employed to rebuild the stock. Geographic information system and cadastral data were sometimes exploited in addition to improve the stock modelling $[13,23,38]$.

\subsubsection{Renovation actions}

Many energy efficiency measures have been investigated in order to improve the building stock performance. Some were related to the building envelope only, in which case renovation actions 
concerned wall, loft and cavity insulation as well as windows replacement [6]. Others referred to the change of energy systems only: e.g. heating, domestic hot water (DHW), ventilation or lighting systems [7]. In most of the papers however, refurbishment of envelope and energy systems have been studied jointly. In addition to the aforementioned renovations actions, other measures have been investigated such as the implementation of PV panels or solar collectors $[11,12,32,37]$, the improvement of heating control strategies $[9,24,35,37]$, the change of the electrical system $[7,23,38]$, the installation of shading devices [33,35], the change of showerheads [7] or office equipment [11]. Three articles combined both maintenance and retrofit of buildings $[30,34,38]$. Other measures have been investigated such as changing water and sewage piping, or improving the fire detection.

Sometimes, renovation actions or combinations of renovation actions may not be appropriate for some buildings in the stock. Constraints are then added in order to avoid these cases. For instance, He et al. [6] removed the option of installing double-glazing for houses already equipped with double-glazed. Keirstead and Calderon [31] added constraints in order to avoid that household have solid-wall and cavity-wall insulation at the same time. García-Fuentes et al. [37] defined rules of incompatibility in order to avoid solutions that are not compatible with the decision makers expectations. On the contrary, it may be appropriate to jointly perform several renovation actions in order to reduce cost and to improve the building performance. Bana e Costa and Oliveira [30] evaluated a degree of synergy in order to identify combinations of renovation actions to be performed at the same time. Furthermore, some renovation actions may have to be done before others and Wu et al. [7] suggested to introduce constraints in the retrofitting sequencing in future works.

\subsubsection{Criteria and constraints}

Several performance criteria have been selected to find the most appropriate renovation strategies at the building stock level. Cost and energy related criteria were the most often chosen as shown in Table 1. Regarding cost criteria, it was intended to minimise the investment cost, the lifecycle cost (LCC), the payback period, or to maximise the savings or the net present value (NPV). Specific models 
assessed the economic performance considering capital expenditures only (CAPEX) or both CAPEX and operating expenditures (OPEX). The terms CAPEX and OPEX are often used by facility and property managers to describe the costs of the building stock. While CAPEX refer to expensive measures such as refurbishment that improve buildings and their value for several years, OPEX involve ongoing expenses such as buildings operation and maintenance costs [40]. In a balance sheet, OPEX are immediately expensed but CAPEX are added to the assets and expensed over multiple years. Regarding energy criteria, the aim was to minimise the energy consumption or to maximise the energy savings. Energy performance criteria were mostly evaluated using steady-state approaches. However, in some case, energy consumption was calculated more accurately using dynamic building energy simulation (DBES) software: EnergyPlus $[6,8,11,12,33,37]$ or TRNSYS [35]. Other criteria have also been taken into account in some studies, including greenhouse gases emissions $[8,9,12,37]$, emissions of $\mathrm{CO}_{2}, \mathrm{SO}_{2}$ and $\mathrm{NO}_{x}[10]$, thermal comfort $[9,33,37]$, compliance with existing regulations [34,36], client satisfaction [34], and cultural heritage preservation [9]. Of the papers reviewed, some considered only one criterion $[13,23,24,31,32,35,38]$, while the majority were framed in a multicriteria context.

In many papers, budgetary constraints have been taken into account $[7,9,10,30,34,37]$ and the renovation cost at the stock level should not exceed the total available budget. Other constraints have also been implemented such as energy savings targets $[7,37]$ and carbon budget $[31,32]$.

\subsubsection{Methods to set priorities}

Four main types of methods have been chosen in order to identify optimal refurbishment scenarios at the building stock level as shown in Table 1, namely: single-objective optimisation (SOO) and MOO, MCDM, sensitivity analysis (SA) and data mining methods. Depending on the method and on the number of criteria, one renovation strategy or a set of renovation strategies have been identified. The questions "which action, which building and during which year" to perform the renovation actions have often been answered with the help of SOO and MOO. Keirstead and Calderon [31] and Jennings et al. [32] carried out a SOO with a mixed-integer linear programming (MILP) approach in 
order to minimise the cost, leading to one optimal refurbishment scenario. Rogeau et al. [13] chose a single-objective framework based on a variant of a knapsack problem in order to maximise the NPV of renovation actions. Nägeli et al. [38] applied a method that takes the deterioration of building components into account and determines the cost-optimal time to perform maintenance and retrofit. In other articles, several objectives have been studied and the optimisation problem was solved by aggregating all objectives into one criterion. Gabrielli and Ruggeri [9] searched the building stock renovation strategy that maximises the weighted sum of four performance criteria. Wu et al. [7] calculated the weighted sum in order to combine two objectives into one objective function, and then optimised the building stock performance with an optimal control approach. Wu et al. [8] and Murray et al. [12] selected the $\varepsilon$-constraint method in order to minimise cost and GHG emissions a MILP SOO framework.

In addition, MOO problems have been solved with Pareto-based strategies. He et al. [6] and Luddeni et al. [11] used the NSGA-II algorithm [41], Taillandier [34] executed a particle swarm optimisation (PSO) [42], and He et al. [10] combined PSO and a GA. Using Pareto-based methods, a set of renovation strategies can be identified; they represent a trade-off between all objectives.

MCDM has been applied in three articles. Bana e Costa and Oliveira [30] ran the MACBETH method (Measuring Attractiveness by a Categorical Based Evaluation TecHnique) [43] to reflect municipal policies in prioritising of the municipal stock refurbishment. Carbonari et al. [36] used the AHP method (Analytic Hierarchy Process) [44] in order to find the school that should be refurbished first. In these two papers, a unique renovation strategy was identified in the output. In García-Fuentes et al. [37], the benefits and costs of each renovation scenarios were evaluated with MCDM and tradeoff solutions between cost and benefits were identified through the concept of Pareto-optimality.

Two studies took advantage of SA to prioritise renovation actions. Mauro et al. [33] identified in a first step the most influential envelope energy efficiency measures on energy demand and thermal comfort using the standard rank regression coefficients (SRRC). In a second step, they investigated 
the cost effectiveness of renovation action including efficiency measures on envelope, and actions on energy systems. Soutullo et al. [35] applied a One-At-a-Time (OAT) approach and could find which renovation actions were the most effective in increasing the energy savings. In addition, Luddeni et al. [11] carried out a SA to identify the most promising energy efficiency measures, before performing a MOO with NSGA-II.

A data mining approach was conducted by Pistore et al. [24] to minimise the energy consumption of schools. They combined wrapper feature selection, random forests and clustering methods to identify cluster of buildings on which a specific renovation action should be prioritised.

In addition, in Österbring et al. [23], a fixed renovation set was applied to all buildings in a city and the cost-effectiveness of this set was assessed, allowing to identify districts or buildings that can achieve significant savings and that should be refurbished first.

\subsubsection{Priorities assessed}

The papers listed in Table 1 aimed at setting priorities in terms of renovation actions, buildings to refurbish or renovation time sequencing. Four papers answered only one of the "which action", "which time" and "which year" questions $[6,33,35,36]$, while the majority answered two or three questions. The most answered question was the "which action" one, i.e. the aim was to set priorities with respect to energy efficiency measures to be applied to the building stock. The "which action" question was complemented by the "which building" question (in eight papers) or by the "which year" question (in two papers). As an example, in Wu et al. [8], optimal renovation actions are determined for each building typologies and scaled-up at the district level. The way to plan renovation over time at the building stock level, i.e. the "which year" question, was less addressed in previous literature. It was investigated in six of the nineteen papers $[7,9,31,32,34,38]$. A renovation schedule was defined, as in Jennings et al. [32] where the optimal time schedule to perform different types of renovation actions in the stock was determined. Besides these six articles, prioritisation in time was indirectly included by a calculation of a degree of urgency in the renovation actions in Bana e Costa and Oliveira [30]. Furthermore, considering the renovation of one building, van de Moortel et 
al. [45] investigated the optimal refurbishment planning in order to determine if a step-by-step renovation approach was more cost-effective than an in-depth renovation performed all at once.

Among the reviewed papers, only three jointly answered the "which action", "which building" and "which year" questions. Each study considered a limited investment budget each year, which is consistent with the aim: in case of an unlimited investment budget, the algorithm would suggest to refurbish all buildings in the first year in order to minimise energy consumption and cost. Wu et al. [7] chose an optimal control approach in order to find the best strategy to retrofit energy systems in the case of a small stock consisting of two buildings. They tried different weightings between their two criteria (energy savings and net present value) and each time got one optimal solution in terms of actions on energy system, building to refurbish, and time scaling. Taillandier et al. [34] identified the best five-year maintenance plans for a set of 22 buildings by means of a particle swarm optimisation. 88 optimal maintenance plans could be identified. The stakeholders eventually ranked a posteriori the optimal plans according to their preferences. In their study, three criteria were taken into account but none of them was related to environmental impacts such as energy consumption or GHG emissions. Gabrielli et al. [9] firstly executed multi-attribute linear programming in order to find one optimal refurbishment strategy for each of the 25 building of their portfolio. Secondly, they prioritised actions and buildings to refurbish over time using urgency and cost-effectiveness indicators, leading to a time distribution of retrofit interventions.

In five papers, other questions were answered. When a large building stock was taken into account (e.g. a city), it was investigated which district should be refurbished in priority $[23,31,32]$. Furthermore, Wu et al. [7] referred to the change of existing facility instead of refurbishment actions as they considered the replacement of energy systems only (changes in the building envelope were not studied). Nägeli et al. [38] likewise referred to actions on building components instead of refurbishment actions as they considered both maintenance actions and energy retrofit actions. 


\subsection{Aim of the article}

The present article aims at proposing and applying a methodology to help portfolio property owner to define appropriate retrofit strategies for their stock by studying the characteristics of a set of optimal renovation schedules. For the optimal solutions, it should point out which type of building of the stock to refurbish first, which type of renovation actions to perform in priority, and in what order to plan the refurbishment when dealing with a funding plan over several years. Furthermore, some of the limitations identified in previous literature are overcome. Firstly, both actions on envelope and energy systems are taken into account. Secondly, cost and environmental criteria are considered as both are important to portfolio property owners. Regarding environmental criteria, the energy consumption is chosen and accurately assessed via a DBES tool to determine the buildings heating loads. Thirdly, all three questions are answered within one optimisation step. Lastly, there is no $a$ priori weighting of the performance criteria, so that stakeholders can choose among a diversity of optimal renovation schedules the one that best fits their preference after having consulted the contents of the schedules. In order to provide a set of optimal schedules, an MOO with an adapted version of the NSGA-II algorithm is run. The multi-criteria decision part is not studied in this article whose focus is on the optimisation methodology and on the identification of the main characteristics of optimal schedules. In the next sections, the methodology is described and then applied to apartment buildings of a portfolio property owner in Greater Paris Area. In the results section, statistical studies carried out on the optimal schedules make it possible to draw conclusions on the renovation to perform as a priority and provide a first level of decision-aid.

\section{Methodology}

In order to find the best renovation schedules for a building stock, the methodology summarised in Figure 1 is applied. After defining the optimisation problem, case study dependent data are fed as an input to the optimisation process. An optimisation algorithm is chosen to find the optimal solutions to the "which action", "which building" and "which year" questions. A large number of renovation 
schedules are explored by the optimisation algorithm and the performance of each one is assessed according to the previously defined objectives and constraints. Then, the algorithm selects Paretooptimal schedules. In the post-processing step, the characteristics of the Pareto-front are analysed. The "Optimisation process" and "Outputs" steps in Figure 1 are central to the methodology and the corresponding algorithms remain unchanged regardless of the building stock studied. The two first steps on the contrary are case study specific and must be adapted to be consistent with the stock under investigation. In that way, the proposed methodology can be applied to any building portfolio (from historic to post-world war II buildings). Further details on the four methodological steps are given in the next paragraphs.

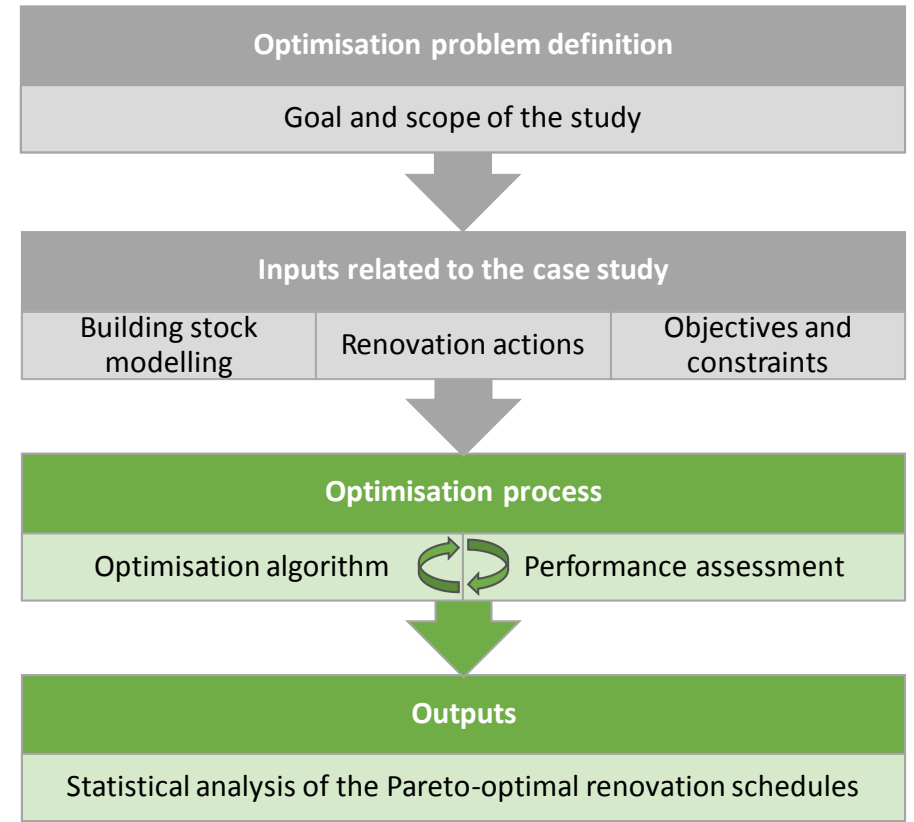

Figure 1: Overview of the methodological steps. Steps 1, 2 depend on the case study, whereas the algorithm in the optimisation process and outputs steps remain unchanged regardless of the studied stock.

\subsection{Optimisation problem definition}

The aim of the studies is to find when and which renovation actions should occur. An MOO algorithm, able to deal with constraints, must be selected. A set of optimal renovation schedules, representing the best trade-offs between several objectives and that can meet several constraints, are therefore analysed in order to define the priorities. 
The performance improvement is studied over an analysis period of $X$ years using the MOO algorithm. Renovation actions are allowed during the $M$ first years of the analysis period. Note that $M$ must be lower or equal to $X$.

Similarly, to previous literature, a bottom-up approach is adopted to represent the stock, with a full description of a set of representative buildings. These representative buildings can be used several times in order to model a real building stock.

As an example, the optimisation problem in the case study is the following: minimise the energy consumption of a stock, modelled as a number of building archetypes, over a period of $X$ years, by a sequence of energy saving measures over $M$ years, under a constraint of a limited yearly budget.

\subsection{Pre-processing step}

Before starting the optimisation process, input data are defined. They are case study dependent. A building stock is chosen, and representative buildings are identified and modelled.

Based on the characteristics of the representative buildings, appropriate renovation actions are defined. The adaptation of the renovation action to the representative buildings is an important step as historic buildings cannot be refurbished in the same way as buildings from the 1970s. In some cases, several renovation actions should be combined for technical or economic reasons. In that case, two options may be considered to input the renovation actions in the algorithm. The first option is to try all single renovation actions separately in the optimisation algorithm and then use a set of predefined constraints; schedules, for which the identified single actions are not combined, are filtered out. The second option is to try only the combined actions. We chose the second option as it reduces the search space and speeds up the convergence. The combined actions are grouped together in a gene which can have a large number of allelic versions.

In addition, in the input step, objectives and constraints that best fit the aim of the study are chosen. As the goal is to find the best way to plan renovation work in time, funding constraints are taken into 
account for each year of the analysis period. Other constraints may be included depending on the specificities of the building portfolio.

\subsection{Optimisation process}

After defining all case study related input parameters, the optimisation process starts. An optimisation algorithm is combined to a DBES tool to assess energy and comfort related objectives. The algorithm was adapted to the context of the renovation of a building stock over several years, so that it is able to deal with multiple buildings, renovation years and constraints.

\subsubsection{Optimisation algorithm}

The well-known genetic algorithm NSGA-II [41] was chosen. As shown in previous literature, genetic algorithms have efficiently served as a tool to improve the performance of new or existing buildings. The characteristics of population members are defined considering genes linked to a chromosome, that exist in different allelic versions. When working at the building scale, each population member is represented by a chromosome and its characteristics are defined by the chosen allelic version of each gene (e.g. adding $10 \mathrm{~cm}$ or $20 \mathrm{~cm}$ of insulation for the gene related to the wall insulation retrofit). One population member therefore corresponds to one version of the same building having different allelic characteristics.

Four parameters have to be set in order to run the algorithm: the number of population members, the crossover and mutation probabilities, and the stopping criterion. They are set based on previous literature and on experience.

\subsubsection{Optimisation platform}

Amapola (a module of the Pleiades ${ }^{2}$ software) manages the optimisation, integrating NSGA-II algorithm and calling the DBES model COMFIE [46] for the evaluation of the solutions (in terms of energy and comfort). The reliability of the reduced multi-zone building model COMFIE has been successfully proven through comparisons with measurements $[47,48]$ and comparisons with international reference models [49-52]. This physic-based model is valid for all types of buildings.

\footnotetext{
${ }^{2}$ https://www.izuba.fr/
} 
A dedicated script calculates the investment costs over $M$ years and the energy operating costs over $X$ years of all population members at each generation. All investment costs are considered as CAPEX (even if only windows are changed), while all energy costs are related to OPEX. The yearly depreciation or the revaluation of the value of the buildings stock (which depend on the completion or not of the renovation works in the current year) are not computed.

\subsubsection{Adaptations for building stock renovations}

The frame of NSGA-II algorithm has to be adapted to deal with the renovation of a building stock over several years. First of all, one population member no more corresponds to a single building, but rather corresponds to a set of $N$ buildings for which renovation work is planned over the $M$ first years. One population member, i.e. one renovation schedule for the building stock is graphically represented in Figure 2, where renovation actions on each building are presented in rows, while the year when renovation actions are taken is shown in columns.

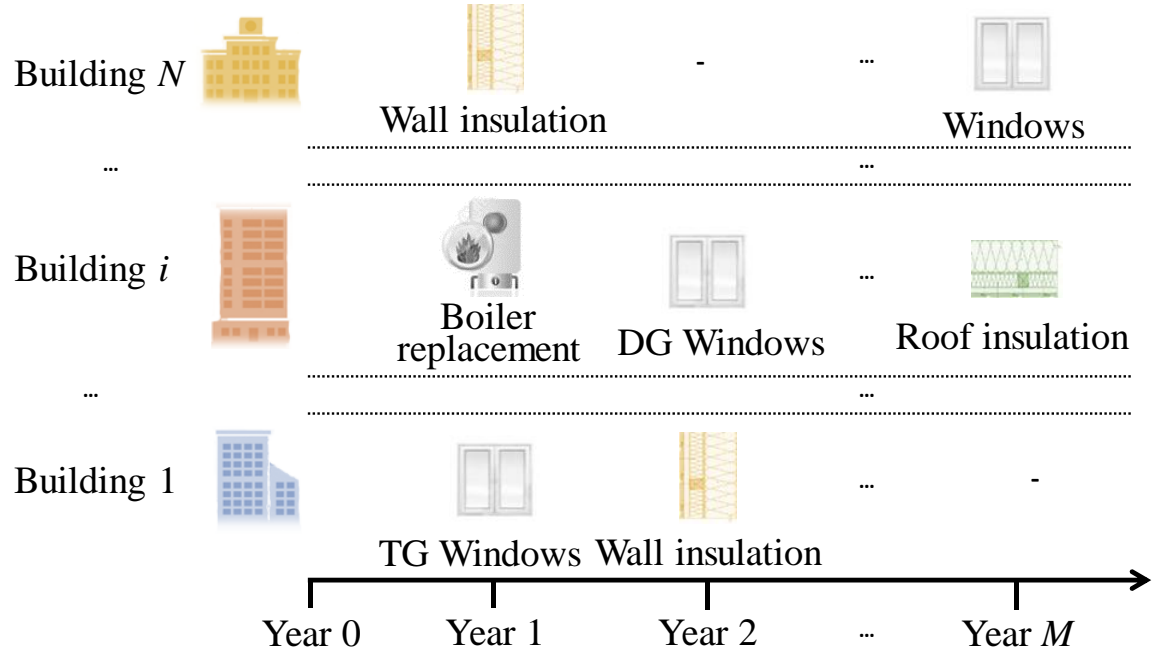

Figure 2: One population member for NSGA-II when refurbishing a building stock over several years. DG: double-glazed, TG: triple-glazed.

For ease of implementation, the genetic information of all buildings was regrouped in the same chromosome, instead of splitting the genetic information over $N$ chromosomes. Thus one chromosome summarises the renovation actions to be performed on all buildings. This chromosome consists in all genes related to building 1 , followed by all genes related to building 2 , and so on until all genes related to building $N$, as shown in Figure 3 . The genes order on the chromosomes is the 
same for each population members. This way of modelling the $N$ buildings has an effect on the crossover operator, which is a single-point crossover in our case. By using a single chromosome for all buildings, the building stock is considered as a whole. In addition, the crossover point can be either within the genes of one building or between two buildings. Note that this modelling choice does not affect the mutation operator as the mutation probability is applied to each gene, independently of the chromosomes.

In order to get optimal renovation schedules, the algorithm should be able to handle multiple renovation years. This sequencing of renovation work in time was done using two chromosomes for each population member, as proposed by Rivallain $[53,54]$ in the context of the optimisation of renovation schedules for one building. A first chromosome called "action chromosome" summarises all renovation actions (i.e. all genes) of all buildings. A second chromosome called "order chromosome" contains the year when the renovation action is taken (i.e. the years when each gene of the action chromosome is activated). The two chromosomes have therefore the same number of genes. The way the genetic information is distributed over two chromosomes is illustrated in Figure 3. Note that the crossover operator is applied to each chromosome independently. Thus the crossover point chosen for the action chromosome may be different from the crossover point of the order chromosome. Furthermore, the mutation operator is applied to each gene of each chromosome.

This way of handling multiple buildings and multiple years in the NSGA-II algorithm allows the questions "which action", "which building" and "which year" to be answered jointly within the same optimisation process. In practice, within the developed algorithm, the performance of each building (i.e. the objectives and constraints) is evaluated for each year, depending on the state of each building on that year, until the year $M$ is reached. Finally, the assessed criteria are aggregated at the stock level and for the $M$ retrofit years. Selections for reproduction and for replacement of population members for the next generation are based on the aggregated criteria. 


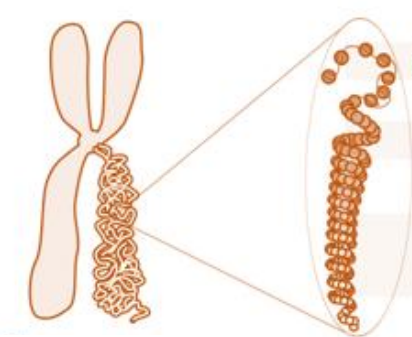

Action chromosome

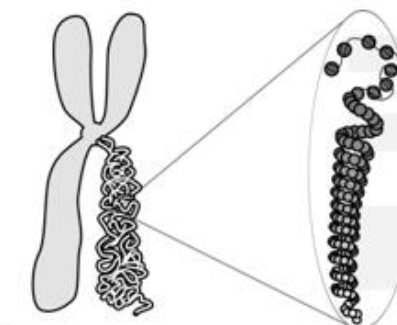

Order

chromosome
Building 1: Windows type

Building 1: Wall insulation thick.

Building $N$ : Windows type

Building $N$ : Wall insulation thick.

Genes

Building 1: Windows change

Building 1: Wall insulation

Building $N$ : Windows change

Building $N$ : Wall insulation

Genes [single glazing, double glazing, ...]

$[10 \mathrm{~cm}, 20 \mathrm{~cm}, \ldots]$

[single glazing, double glazing, ...]

$[10 \mathrm{~cm}, 20 \mathrm{~cm}, \ldots]$

Alleles

[year 1, year $2, \ldots$, year $M$ ]

[year 1 , year $2, \ldots$, year $M$ ]

[year 1, year 2, .., year $M$ ]

[year 1 , year $2, \ldots$, year $M$ ]

Alleles

Figure 3: Genetic information representation with two chromosomes

Lastly, the optimisation algorithm was adapted in order to deal with multiple constraints. As the aim is to find optimal renovation schedules under multi-year funding constraints, the algorithm was adapted to deal at least with costs constraints but other kinds of constraints such as energy savings constraints can also be integrated. Two kinds of cost constraints can be taken into account: yearly investment and global investment. The multi-year funding constraints are considered as soft constraints that can be exceeded by $10 \%$. However, global funding constraints over the $M$ years are implemented as hard constraints and are not allowed to be exceeded. For each population member, the amount of investment for all buildings is assessed for each year from year 1 to year $M$. For one given year, if the amount of investment exceeds $110 \%$ of the available budget for that year, the constraint for that year is not met and the counter of exceeded constraints is incremented by a value of $1 / M$. On the contrary, if the amount of investment remains below the available budget for that year, the budget that has not been expended is added to the following year's budget. In addition, the amount of investment of all years is added to get the global investment on the $M$ first years. If the global invested amount exceeds the global budget, the counter of exceeded constraints is incremented by a value of 1 . Note that the counter of exceeded constraints is incremented in such a way that the same weight is given to the global investment constraint as to all yearly constraints 
taken together. Thus, the influence of exceeding the budget during only one year is less important than exceeding the global budget. In the NSGA-II algorithm, during the selections for reproduction and for replacement, population members are preferred over others if their counter of exceeded constraints is lower.

As explained in 2.2, some renovation measures should not be performed independently, e.g. replacing windows will generally influence air renewal by reducing infiltration, which may lead to modifications of the ventilation system. In order to account for such aspects, combined renovation actions are considered and grouped within one gene. This gene may have a large number of allelic versions as several types of windows replacement and ventilation systems may be jointly chosen. This adaptation in the genetic modelling does not change the genetic processes. In the initial population, one of the many allelic versions of the gene (e.g. double glazing and single flow ventilation) is randomly chosen and then population members evolve through crossover, mutation and selection.

\subsubsection{Adaptations to decrease the optimisation process time}

In our context, various renovation actions can be applied on many buildings, studied over many years. This leads to a large amount of possible renovation schedules, potentially slowing down the convergence speed of the optimisation algorithm. In order to make the search of optimal schedules more efficient, some trivial solutions are included in the initial population, as suggested by Machairas et al. [17]. Contrary to the usual random initialisation, the population of the first generation is customised using expert knowledge: the allelic characteristics of some population members are replaced by those of members who are assumed to be part of the final Pareto front. For example, if the two objectives to minimise in the optimisation are the energy consumption of the building stock over $M$ years and the global investment, two renovation schedules appear to be trivial. Firstly, the "no building is renovated" population member is an extremum of the final Pareto front as it will lead to the highest energy consumption and the lowest investment. Secondly, the population member "all buildings are refurbished to reached the highest energy performance" is the other extremum of the 
Pareto front leading to the lowest energy consumption and to the highest investment. It might be difficult for the algorithm to find these two extrema due to the large number of possible schedules: including them in the initial population is useful to bring more diversity from the first generation.

One combination of renovation actions for one reference building can occur in many renovation schedules. For instance, two population members in the same generation or in different generations may have one building with the same combination of renovation actions. In addition, if the renovation works start on year 3 for one building, the building state is the same in years 1 and 2 . In order to avoid multiple evaluations of energy and cost performances for a same building state, all DBES and cost assessments are carried out at the beginning of the optimisation process for all possible states and an archive of building state performance is generated.

\subsection{Post-processing step}

The optimisation process provides a set of optimal refurbishment schedules for the studied building stock. The characteristics of these optimal solutions are statistically analysed in order to draw conclusions on how these building stocks should be refurbished. Renovations that are more likely to be performed during a given year of the multi-year plan are identified. This helps buildings property managers to set priorities.

\section{Case study}

The methodology was applied in order to find the optimal renovation schedules for a social housing portfolio under multi-year funding constraints. The portfolio is a virtual building stock that was modelled using data of a real building stock, provided by a portfolio property owner in the city of Montreuil in Greater Paris Area, France. The organisation owns social housing in several districts of the city. For economic, social and environmental reasons, it has identified two districts of its portfolio to be refurbished in priority, and needs assistance to define renovation priorities within these two districts. A five-year planning of renovation works was considered in order to be consistent with the 
funding plan time-scale chosen of the organisation. Based on an in-depth analysis of the characteristics of the optimal schedules, the aim of this study was to help the owner to define the renovation actions to perform, the buildings to refurbish and the planning.

\subsection{Location and climate}

The two districts are located in Montreuil, a French municipality bordering Paris to the east. France has a temperate climate with five main sub-regional climates [55] and historically buildings are designed to reduce heating consumptions. More specifically, Paris as the centre of France are characterised by a semi-oceanic climate, i.e. the temperature differences between summer and winter are greater than at seaside, while rainfall is lower. In this study, the climate was modelled using a typical climate file from the current French building energy regulation (RT2012 [56,57]), created from observed data over the period 1994-2008. 58,330 heating degree-hours (with $18{ }^{\circ} \mathrm{C}$ as standard reference temperature) are taken into account in the file to describe the climate appropriately.

\subsection{Portfolio modelling}

A virtual social housing stock was modelled based on the characteristics of the buildings in the two districts to be refurbished in priority. In these two districts, two types of buildings can be found: on the one side, low-rise large multifamily house buildings that are called "large apartment blocks" and denoted "B" in the following, and on the other side, high-rise multifamily house buildings that are called "towers" and denoted " $T$ " hereafter. In each district, every building had been built in the same period and previously refurbished at the same time. Therefore, within one district, all buildings share the same constructive characteristics and the same energy class (from A=best to $G=$ worst performance) according to the available energy performance certificates. The characteristics of the two districts, that consist in 21 buildings in total, are summarised in Table 2. 
Table 2: Characteristics of the two districts to refurbish

\begin{tabular}{|c|c|c|c|c|c|}
\hline District & $\begin{array}{c}\text { Number of } \\
\text { buildings }\end{array}$ & $\begin{array}{c}\text { Number of } \\
\text { dwelling units }\end{array}$ & $\begin{array}{c}\text { \% of dwellings in large } \\
\text { apartment blocks }\end{array}$ & $\begin{array}{c}\text { \% of dwellings in } \\
\text { towers }\end{array}$ & $\begin{array}{c}\text { Energy } \\
\text { class }\end{array}$ \\
\hline District 1 (D1) & 6 & 581 & 87 & 13 & $\mathrm{D}$ \\
\hline District 2 (D2) & 15 & 579 & 85 & 15 & $\mathrm{E}$ \\
\hline
\end{tabular}

As it would be time consuming to model in detail and to perform simulation on every building, a set

of three representative buildings was chosen in a first step: one large apartment block in district 1

(D1), and one large apartment block and one tower in district 2 (D2). The characteristics of the three representative buildings are given in Table 3 and pictures of the buildings are shown in Figure 4 .

Table 3: Characteristics of the three representative buildings

\begin{tabular}{|c|c|c|c|c|c|c|}
\hline District & Typology & $\begin{array}{c}\text { Number of } \\
\text { dwelling units }\end{array}$ & $\begin{array}{c}\text { Year of } \\
\text { construction }\end{array}$ & Wall insulation & Roof insulation & $\begin{array}{c}\text { Energy } \\
\text { class }\end{array}$ \\
\hline D1 & B with 5 storeys & 72 & 1957 & $\begin{array}{c}5 \mathrm{~cm} \text { insulation } \\
\text { material set in a } \\
\text { previous retrofit }\end{array}$ & $\begin{array}{c}\text { Flat-roof } \\
\text { insulation }\end{array}$ & D \\
\hline D2 & B with 5 storeys & 60 & 1964 & None & $\begin{array}{c}\text { Unoccupied loft } \\
\text { insulation }\end{array}$ & E \\
\cline { 2 - 3 } & T with 10 storeys & 29 & \multicolumn{2}{|r}{} \\
\hline
\end{tabular}




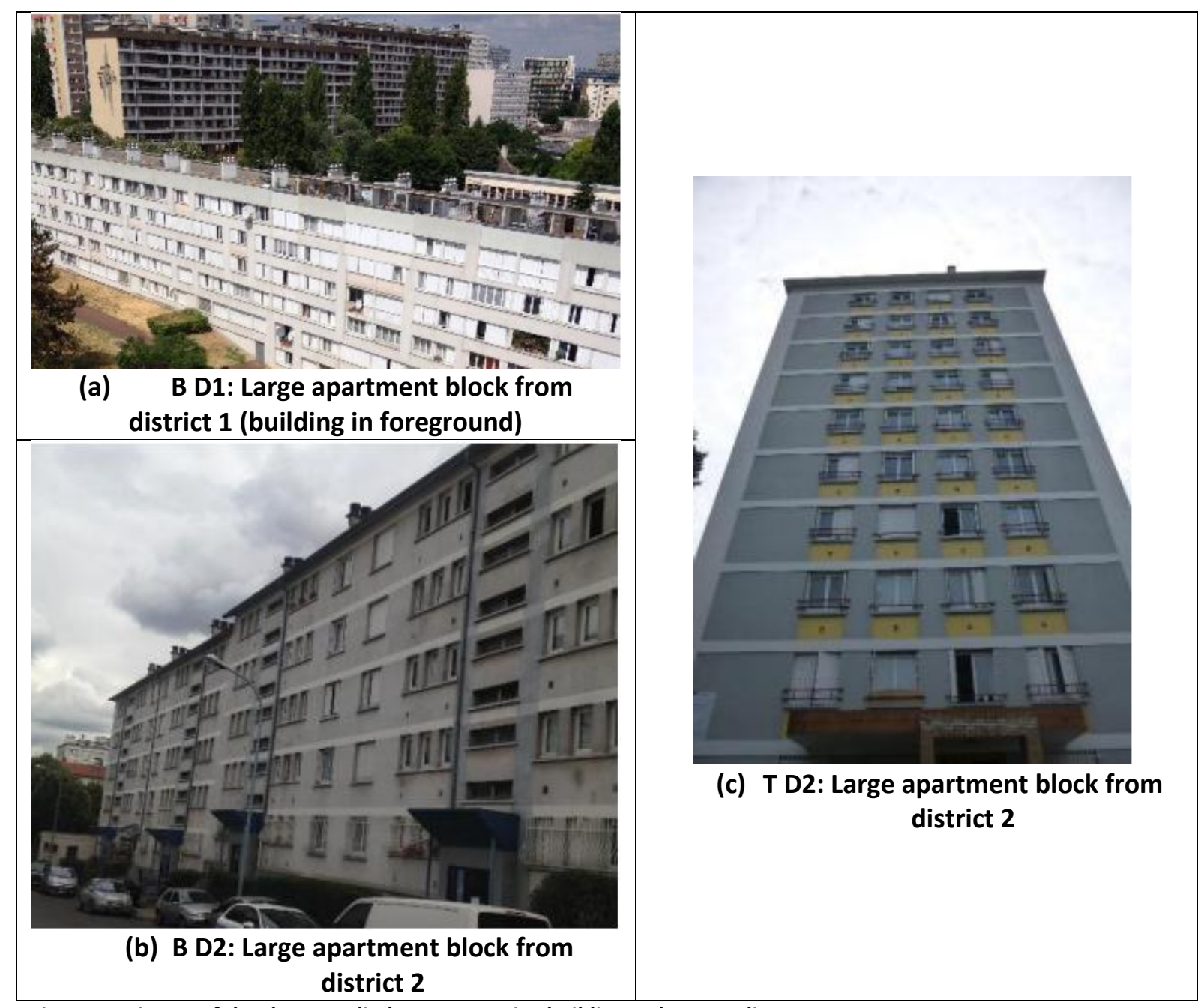

Figure 4 : Picture of the three studied representative buildings. Photo credits: OPHM.

In the studied districts, two orientations are possible for the large apartment blocks: the two largest façades can be oriented to the East and West (E-W), or they can be oriented to the North and South (N-S). As the tower has an almost square base, the orientation has less influence on this building. In order to take into account the two possible orientations for blocks in the virtual portfolio, 5 morphologies of buildings were defined, from on the three real buildings, in a second step.

In a third step, a virtual building stock was modelled. The number of buildings of each morphology was chosen so that the share of dwellings of energy class $E$ as well as the share of dwellings in tower are representative of what is observed in the two real districts. In order to reduce the search space of the optimisation algorithm, 7 buildings were chosen according to these rules. The characteristics of the virtual portfolio are given in Table 4, and the three steps used to model the virtual portfolio are summarised in Figure 5. 
Table 4: Characteristics of the virtual portfolio considered in this study

\begin{tabular}{|c|c|c|c|c|}
\hline District & Typology & Orientation & $\begin{array}{c}\text { Number of } \\
\text { buildings }\end{array}$ & $\begin{array}{c}\text { Number of } \\
\text { dwellings }\end{array}$ \\
\hline \multirow{2}{*}{ D1 } & B with 5 storeys & E-W & 1 & 72 \\
\cline { 2 - 5 } & B with 5 storeys & N-S & 2 & 144 \\
\hline \multirow{3}{*}{ D2 } & B with 5 storeys & E-W & 2 & 60 \\
\cline { 2 - 5 } & B with 5 storeys & N-S & 1 & 60 \\
\cline { 2 - 5 } & T with 10 storeys & - & 1 & 29 \\
\hline
\end{tabular}

\begin{tabular}{|c|c|c|}
\hline $\begin{array}{l}\text { Step 1: } \\
\text { Selection of representatives } \\
\text { large apartment blocks (B) } \\
\text { and housing towers (T) in } 2 \\
\text { districts to refurbish in } \\
\text { priority } \\
\text { - District } 1 \text { (D1): 1 B } \\
\text { District } 2 \text { (D2): } 1 \mathrm{~B}+1 \mathrm{~T} \\
>3 \text { representatives } \\
\text { buildings }\end{array}$ & 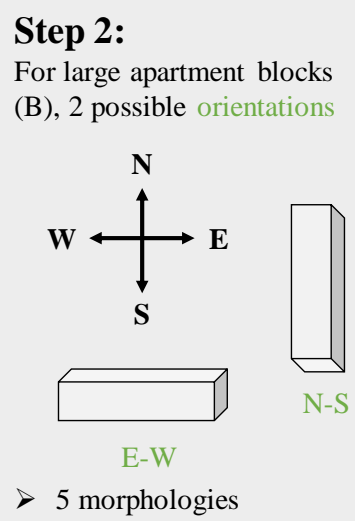 & $\begin{array}{l}\text { Step 3: } \\
\text { Creation a of virtual portfolio } \\
\text { representative of the real one: } \\
\text { - Same share of housing in } \\
\text { energy classes D and E } \\
\text { - Same share of housing in } \\
\text { B and in } T \\
\text { Virtual portfolio of } 7 \\
\text { buildings = } \\
\text { 2 B D1 N-S + 1 B D1 E-W } \\
+1 \text { B D2 N-S + 2 B D2 E-W } \\
+ \text { 1 T D2 }\end{array}$ \\
\hline
\end{tabular}

Figure 5: Modelling process of the virtual social housing portfolio

Each building of the virtual portfolio is refurbished independently of the others. For instance, the two large apartment blocks of D1 with a N-S orientation may be refurbished differently.

\subsection{Renovation actions}

The practicable renovation actions for this stock were discussed with an engineering design office.

Actions on envelope and systems were studied. Several renovation actions were combined for technical or economic reasons. For each building, four groups of combined actions, corresponding to four genes in the "action chromosome", were investigated. They are related to façade refurbishment, loft insulation, cavity insulation and energy systems replacement, as shown in Figure 6. 


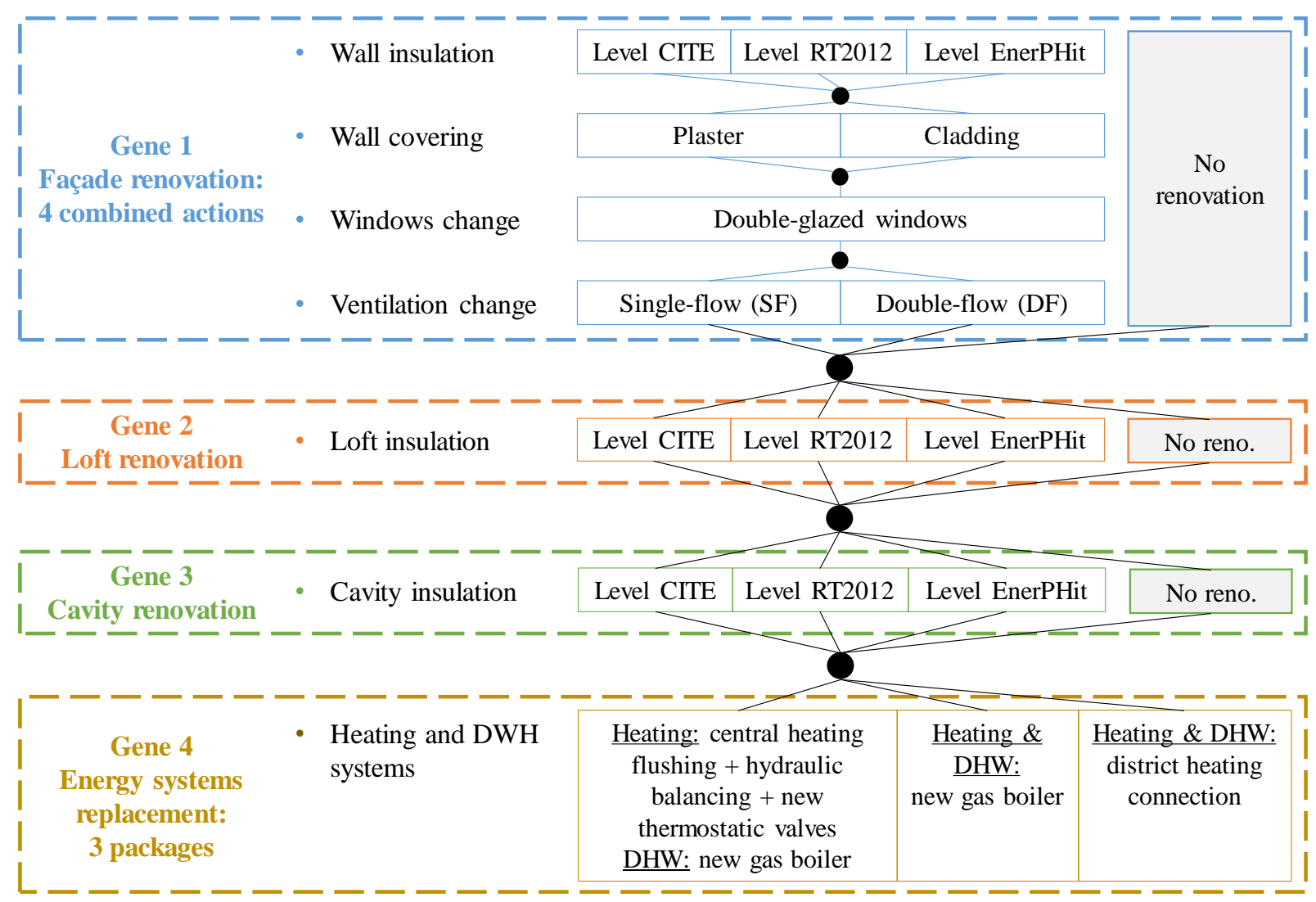

Figure 6: Groups of combined renovation actions to be applied to the virtual portfolio

Regarding façade refurbishment, four actions were combined: wall insulation, wall covering, windows replacement and ventilation replacement. When refurbishing a façade, it is obvious to both change the insulation and the covering. Refurbishing the walls and changing the windows at the same time is more cost effective as costs e.g. for scaffolding occurs only once. Furthermore, it is advised to refurbish the façade and the ventilation system at the same time because keeping the old ventilation system together with the new façade that have an increased air tightness could lead to moisture and air quality issues. Three insulation levels were investigated for external walls: a minimum level to reach a French tax credit for the renovation (CITE), a medium level corresponding to the French regulation level for new buildings (RT2012), and a high level corresponding to the Passivhaus renovation level (EnerPHit). Two façade coverings are possible: plaster and cladding. For windows, only one option was studied (a double glazed windows with a $U$ value of $1,4 \mathrm{~W} / \mathrm{m}^{2} / \mathrm{K}$ ) which is currently the most sold type of windows and therefore the most cost effective option. For the ventilation, single-flow and double-flow were investigated. Finally, twelve combinations of 
renovation are possible for gene 1 . A $13^{\text {th }}$ combination was added: it corresponds to the case where the façade is not refurbished.

For gene 2, three levels of loft insulation were investigated. In addition, the absence of loft renovation is investigated. Similarly, for gene 3, four allelic versions are possible for the cavity insulation.

Regarding the change of heating and DHW in gene 4, the "no renovation" alternative is not studied, as it is necessary for safety reason to replace the bath-heathers currently installed in each dwelling. Three renovation packages, corresponding to three allelic versions of gene 4 , were investigated. In the first one, small maintenance actions are performed on the heat distribution system and a new collective gas boiler is installed for DHW. In the second package, a new collective gas boiler is installed for heating and DHW and small maintenance actions are conducted on the heat distribution network. In the third package, a connexion to the local district heating is considered for heating and DHW, and maintenance actions on the heat distribution network are undertaken.

It is worth mentioning that the renovation actions listed above are appropriate for the buildings of the studied districts. For other types of building such as historic buildings, another set of renovation actions has to be defined in concertation with an engineering design office; external insulation being for instance not suitable.

Costs of renovation actions were defined with a partner engineering design office and are listed in Table 5. The connection to the district heating was free in this case study: due to the high future potential benefits, the energy provider was willing to pay for this investment if the social portfolio property owner gradually connected its building stock to the grid. 


\begin{tabular}{|c|c|}
\hline Actions & Costs (material and installation) \\
\hline Plaster + rock wool & $120 € / \mathrm{m}^{2}$ (EnerPHit level) \\
\hline Cladding + rock wool & $250 € / \mathrm{m}^{2}$ (EnerPHit level) \\
\hline Rock wool for loft insulation & $46 € / \mathrm{m}^{2}$ (EnerPHit level) \\
\hline Rock wool for cavity insulation & $57 € / \mathrm{m}^{2}$ (EnerPHit level) \\
\hline Polyurethane for flat roof insulation & $78 € / \mathrm{m}^{2}$ (EnerPHit level) \\
\hline Removal of old insulation material & $15 € / \mathrm{m}^{2}$ \\
\hline Windows replacement & $200 € / \mathrm{m}^{2}$ \\
\hline Windows frame covering & $65 € / m$ \\
\hline Rolling shutters & $140 € / \mathrm{m}^{2}$ \\
\hline Scaffolding & $7 € / m^{2}$ \\
\hline Walls preparation work & $12 € / \mathrm{m}^{2}$ \\
\hline Single-flow ventilation & $750 € /$ stairwell $+75 € /$ air inlet \\
\hline Double-flow ventilation & $3,500 € /$ dwelling \\
\hline Central heating flushing & $1,000 € /$ building \\
\hline Hydraulic balancing & $100 € /$ dwelling $+100 € /$ riser pipe \\
\hline Thermostatic valves & $75 € /$ valve \\
\hline Expansion vessel & $3,000 €$ for 1,000 litters \\
\hline New gas boiler and distribution & $25,000 € /$ stairwell $+25,000 € /$ riser pipe $+750 € /$ dwelling \\
\hline Connection to the district heating + substations & $0 €$ \\
\hline
\end{tabular}

In this study, 208 combinations of building envelope are possible for each building (combinations of alleles of genes 1, 2 and 3). 208 DBES are therefore required to evaluate the heating load for each building. For each DBES, 3 packages of energy systems are practicable, leading to 624 combinations of renovation actions for one building. Each of the four groups of combined renovation actions can take place during the years 1 to 5 (given that a five-year planning was considered), meaning that five levels are possible for each of the four groups. For each building $3.90 \times 10^{5}$ combinations of timescheduled actions are thus possible. Finally, according to the number of possible renovation actions per buildings, the number of buildings, and the renovation work period, the number of possible renovation schedules reaches $1.37 \times 10^{39}$. The number of DBES is small compared to the number of schedules. Running all DBES simulations at the beginning of the optimisation process and archiving the results, instead of running DBES for each schedule reduce the process time by several orders of magnitude.

\subsection{Objectives and constraints}

Two objectives that are important to the portfolio property owner are taken into account in this study: minimise the global investment cost and minimise the final energy consumption for heating. 
The global investment cost corresponds to CAPEX over 5 years. Only the CAPEX is included in the study because it appears to be the key point for the portfolio owner, the OPEX been offset by the rents of the tenants. The energy consumption is cumulated over 20 years as it is assumed that if the district is refurbished, no further renovation will take place over the next 20 years. Minimising the energy consumption for heating will tend to reduce the share of charges in the rent of the tenants. For other case studies, it might be necessary to include both CAPEX and OPEX in the cost analysis.

Given these two objectives, two trivial renovation schedules were included in the initial population for the optimisation step. The first solution corresponds to the case in which no renovation action is taken on genes 1 to 3 , and buildings are connected to the district heating during the first renovation year. It leads to the lowest investment cost and to a high cumulated heating consumption. The second solution corresponds to the case in which all buildings are refurbished to reach the best energy performance (EnerPHit level, double-flow ventilation system and connection to the district heating) from the first renovation year. This leads to the lowest cumulated energy consumption and a high investment cost. This point is an extremum when no constraints are considered.

Five multi-year funding constraints (i.e. one for each renovation year) and one global funding constraint were considered. For the multi-year funding constraints, the yearly available budget was $1 / 5^{\text {th }}$ of the total budget.

Other quantities of interest can be calculated within the optimisation platform (comfort indicators, GHG emissions for heating...). Even though they were not used in this case study, they can be useful in the final decision process in order to choose the most appropriate renovation schedule.

\section{Results}

\subsection{Preliminary results}

\subsubsection{Algorithm settings}

Different tests were conducted in order to increase the algorithm performance for our case study. The performance was assessed using the evolution of the Pareto-front over generations, as well as 
the normalised hypervolume [58] (i.e. the volume delimited by the normalised Nadir point and the normalised points of the Pareto-front). The tests showed that increasing the numbers of members per generation makes the convergence slower at the beginning of the process (i.e. it took more generations to reach the same hypervolume value). Furthermore, when the crossover probability increased or when the mutation probability decreased, the convergence was faster at the beginning of the process. Recht [59] found similar conclusions in terms of convergence for another case study.

Due to the high number of possible renovation schedules and the potentially large number of Paretooptimal schedules, the population size was set to 260 members. Considering the evolution of the hypervolume, the algorithm was stopped after 1,500 generations; this type of stopping criterion is the most frequently applied according to Costa-Carrapiço et al. [4]. This number of generations is high compared to what is frequently observed in the literature. It was chosen for a research purpose in this work as the number possible schedules is high. The crossover probability was 0.9 and the mutation probability was 0.5 . The mutation probability was set at this high value in order to favour the diversity and to reduce the rate of duplicated members. Using the previously mentioned parameters values, each optimisation took around $72 \mathrm{~h}$ on a 2 cores laptop with a i7-6850U processor of $1.9 \mathrm{Ghz}$.

\subsubsection{Algorithm validation}

Two preliminary analyses were run in order to validate the algorithm adaptations. In the first one, the time sequencing was not taken into account and all renovations were performed within one time period. Furthermore, the budget was unlimited. The statistical analysis of the characteristics of Pareto-optimal schedules showed that buildings from D2, that initially had a lower energy efficiency (class E) were more likely to be refurbished than buildings of D1 (initially of class D). Regarding the change of heating and DHW systems, all Pareto-optimal solutions were linked to the district heating as this solution has the lowest investment cost and the higher energy performance. In addition, for the wall covering, plaster was preferred over cladding due to the lower cost of this alternative for a similar energy performance. 
In the second preliminary analysis, the "which year" question was added and renovations could be planned within 5 years. However, yearly and global budgets were unlimited. In this case, the algorithm should converge towards the same renovation actions for the same buildings as during the first analysis. Furthermore, with the budget free, all actions (100 \%) should be undertaken during the first year for Pareto-optimal schedules. The observed results were close to those expected. As shown in Figure 7, the Pareto front of this second analysis (with planning, i.e. within 5 years) is close to the one of the first analysis (without planning, i.e. within 1 year), especially for low investments, i.e. when few renovation actions are performed. Due to the inclusion of trivial solutions, the two Pareto fronts share the two same extrema. Regarding the actions set, $94 \%$ of the façade renovations (the most expensive combination of renovation actions) are carried out during the first year. In addition, $47 \%$ of the cavity renovations, $43 \%$ of the loft renovations and $83 \%$ of the system replacement were programmed during the first year. The small gaps between expected and observed results can be explained by the convergence which was not completely reached. The results of the two preliminary analyses are detailed in Pannier et al. [60]. In view of these small gaps, the algorithm adaptations have been validated and more realistic studies were performed as presented in 4.2.

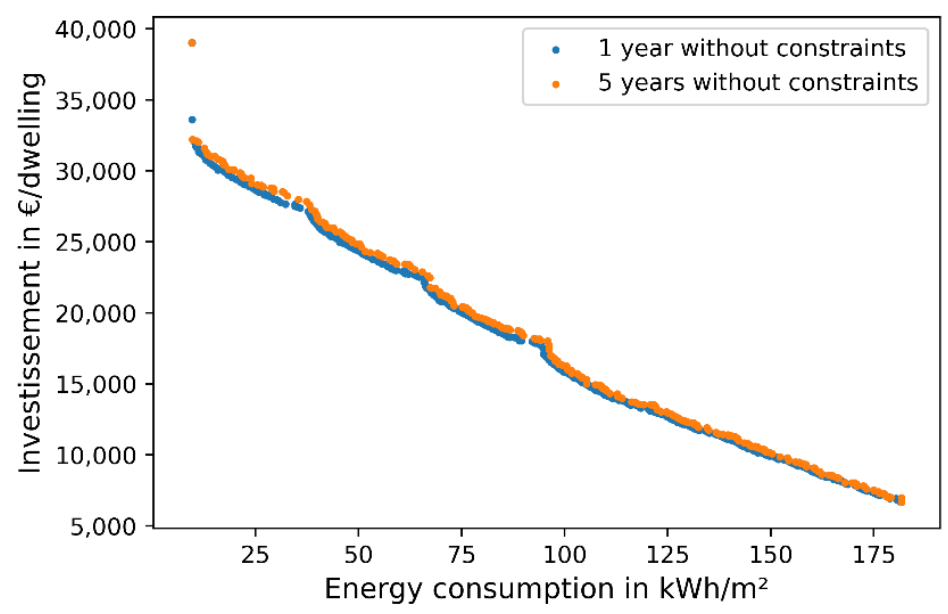

Figure 7: Pareto fronts for the two preliminary analyses

\subsection{Results of the case study}

In the results presented in the next paragraphs, yearly and global budget constraints are taken into account, allowing to answer the "which action", "which building" and "which year" questions for the 
case study. Two funding alternatives were studied. In the first one, the global budget is sufficient in order to renovate all buildings of the stock to the best energy performance. This first alternative is denoted "full F" for full funding hereafter. In the second alternative, the global available budget reaches half of the total budget required to renovate buildings with the best energy performance. This second alternative is denoted "half F" for half of the funding hereafter. In both alternatives, the yearly budget corresponds to $1 / 5^{\text {th }}$ of the global budget.

The evolution of the normalised hypervolume with the number of generations is plotted in Figure 8 . From the first generation the hypervolume value is high as trivial solutions were included in the first population. The hypervolume continuously increases generation after generation, showing that the algorithm continues to find new optimal schedules. Due to the more severe constraints taken into account in "half F", the hypervolume of this alternative is smaller. After 450 generations for "full F" and 300 generations for "half", the hypervolume increases at a slower rate but the process was continued until 1,500 generations in order to have more population members in the Pareto-front and therefore more diversity in the optimal schedules.

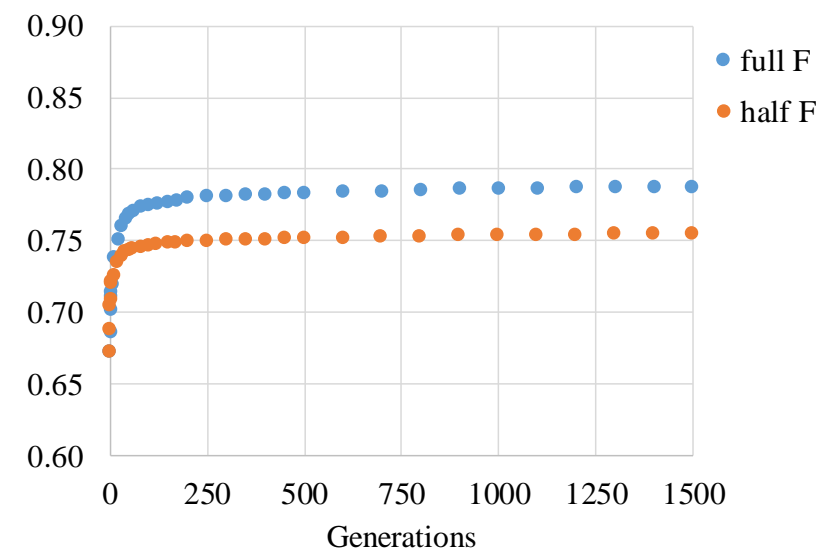

Figure 8: Evolution of the normalised hypervolume over the generations

The evolution of the Pareto front is plotted in Figure 9 for the "full F" alternative. After 50 generations, a lot of optimal schedules from generation 1500 are missed. The Pareto-front of generation 300 and 1500 share a lot of optimal schedules, especially for low investments. Extending the number of generations from 300 to 1500 is useful if more information on schedules with a high 
investment is required. For a research purpose, results of the Pareto front at the generation 1500 are further analysed in the next paragraphs.

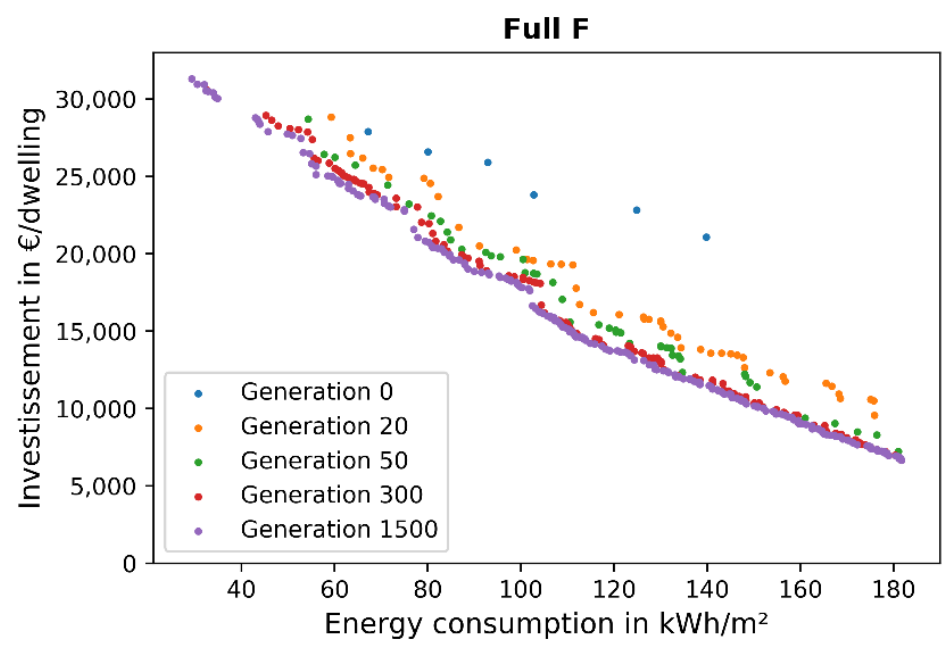

Figure 9 : Evolution of the Pareto front from generation 0 to generation 1500

The Pareto fronts reached at generation 1,500 are plotted in Figure 10. The objectives values units at the building stock level are in $€ /$ dwelling for the investment and $\mathrm{kWh} / \mathrm{m}^{2} /$ year for the mean energy consumption over 20 years, as these metrics are significant to the portfolio property manager. The lower part of the Pareto fronts is similar in both alternatives and they share the same extremum that was included as a trivial solution. Due to the yearly budget constraint, the second trivial solution was not kept in the Pareto front but previous tests had shown that it allowed to produce more diversity in other solutions. Due to the more severe yearly constraints considered in "half F", less money is invested in this second alternative, which results in higher energy consumption for a same investment level. 


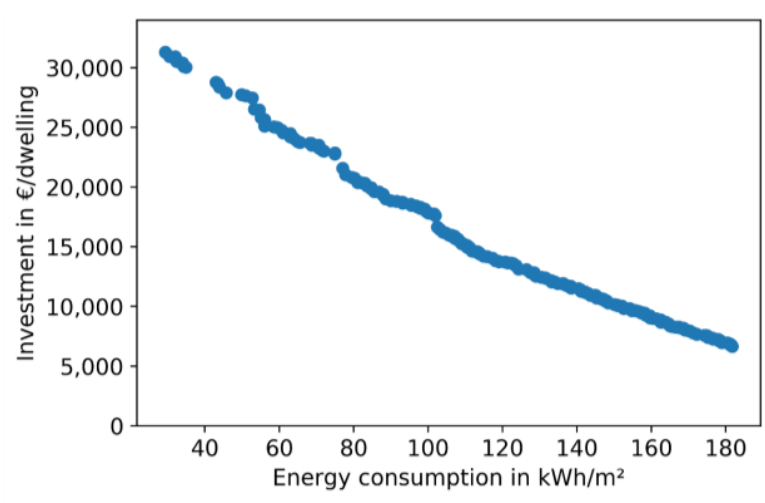

$\underline{\text { full F }}$

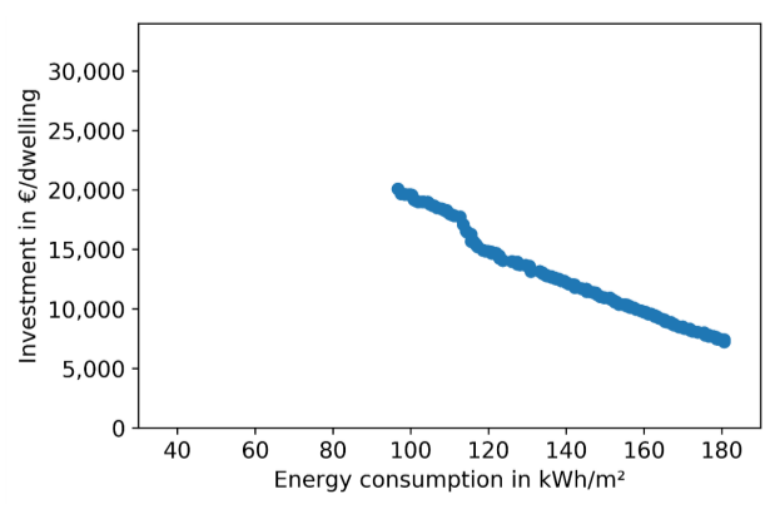

$\underline{\text { half } F}$

Figure 10: Pareto-front for the alternative "full F" (left) and "half F" (right)

In the "half F" alternative, a change of slope is observed in the Pareto front in Figure 10. This change is linked to the way one additional euro is allocated to the buildings as shown in Figure 11. In the two graphs of Figure 11, Pareto optimal schedules are ranked by increasing investment order and the investments and energy consumption per building are plotted. For low investment, small renovations are started. From the $18^{\text {th }}$ member, more money is invested in the tower T D2. Consequently, the consumption for this building decreases significantly. Then from member 41 to member 126, different investments are selected in order to reduce the global energy consumption. Expensive renovation actions are undertaken for each building of district D2 resulting in a high reduction of their energy consumption. From member 126, large actions are performed on each building of D2 and additional actions to reduce their consumption are less expensive and less efficient. This explains the slope increase. Finally, from member 137, costly actions are selected on buildings of D1, leading to the second change of slope. Investments in D1 first result in a decrease on the investments in B D2 $\mathrm{N}-\mathrm{S}$. For higher investment, B D1 E-W both buildings of D2 and are refurbished. 

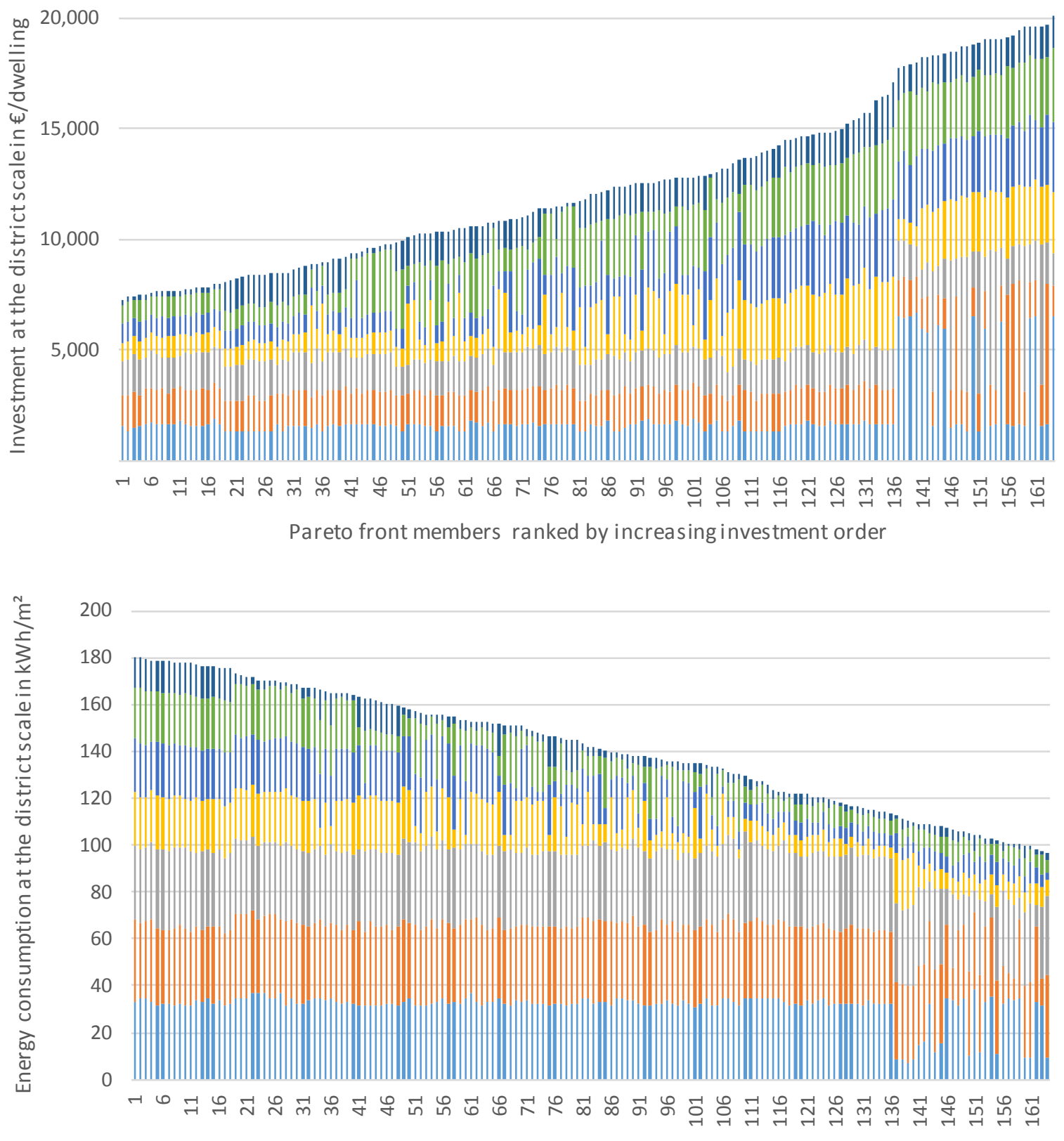

Pareto front members ranked by increasing investment order

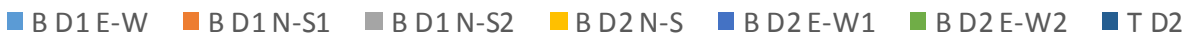

Figure 11 : Investment (upper graph) and energy consumption (lower graph) of optimal schedules for the "half $F$ " alternative

Investment and energy consumption may vary significantly between both districts and from one building to another. The distribution of energy consumption and investment of Pareto optimal schedules is given in Figure 12 for the seven buildings considered in the case study. In the violin 
boxplots ${ }^{3}$, the red mark corresponds to the mean and the orange one to the median value. The violet cross represents the final heating energy consumption before renovation. In this case study, energy retrofit costs per dwelling range from 1,000 to $40,000 €$ depending on the building, and investments above $25,000 €$ per dwelling are uncommon. These results are consistent with those of a study conducted in six European countries, where the CAPEX in social housing were found to range from 21,000 to $46,000 €$ par dwelling with the energy portion ranging from 9,000 to $17,500 €[61]$.

It can be observed from Figure 12 that statistically, more money is invested in the buildings of district D2 that had a higher energy consumption before the renovation actions (class $\mathrm{E}$ ). The total energy consumption is more likely to be lower in the buildings of district D2 after the renovation. The higher investment and the lower consumption for D2 are explained by the actions applied: as shown later in Figure 13, the expensive and efficient combination of renovation actions of gene 1 is more likely to be applied to D2. When the budget constraints are higher (alternative "half F"), investments are strongly reduced in the apartment blocks of D1. Furthermore, for the apartment blocks of D2, the average investment slightly decreases for the "half $F$ " alternative. In that case, the priority is given to the tower for which the investment level remains high. For this building, the maximal investment can be higher in "half $F$ " than in "full F" as the algorithm has explored the more expensive cladding option for the wall covering in "half F", while in "full F" the wall covering is always plaster as displayed in Figure 13.

\footnotetext{
${ }^{3}$ A violin boxplot is a graph combining a boxplot and a kernel density estimate of the distribution.
} 

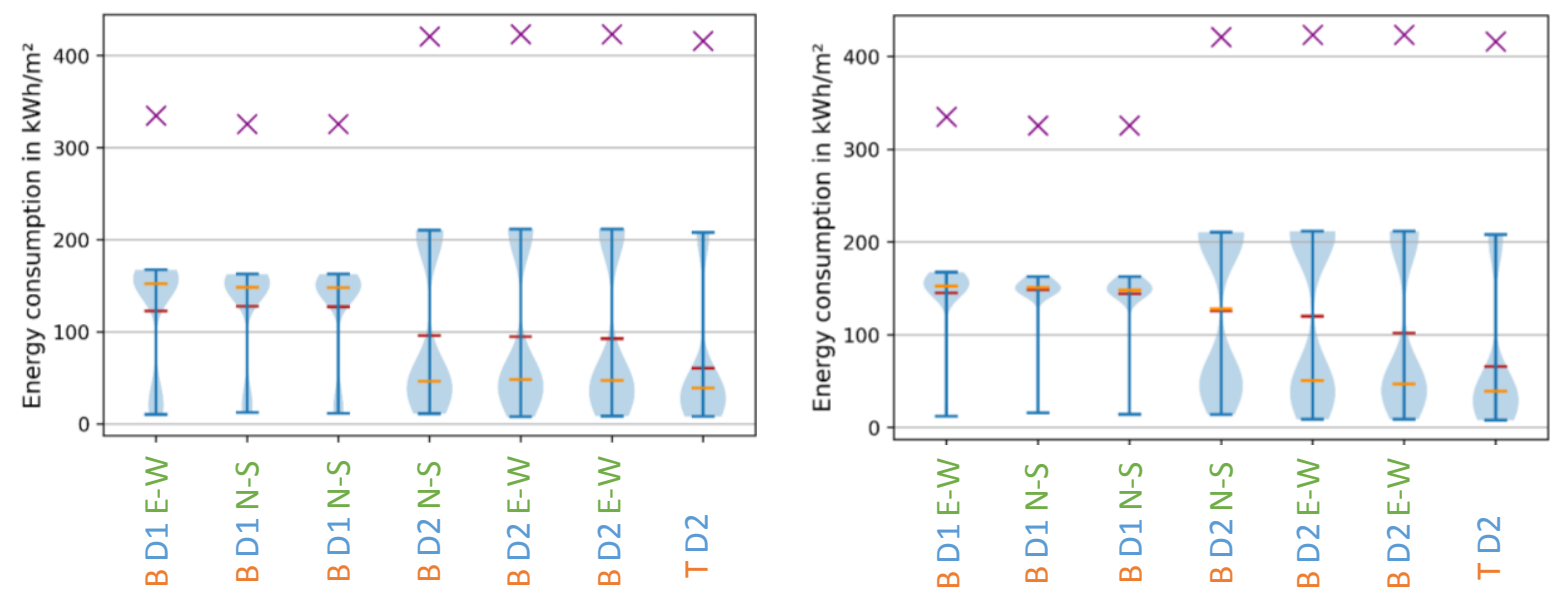

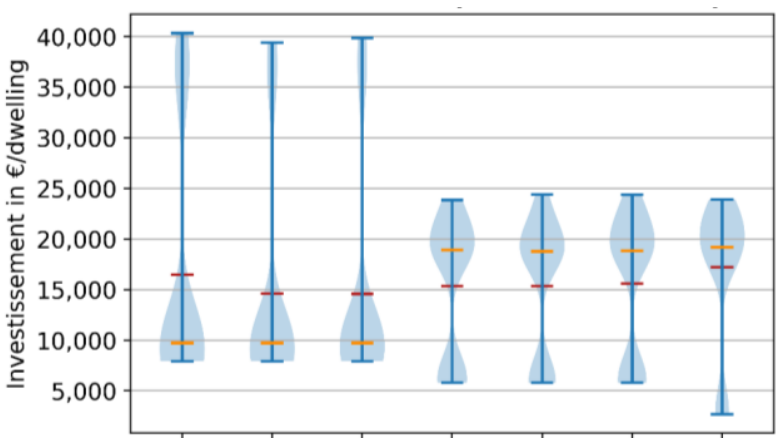

full $F$

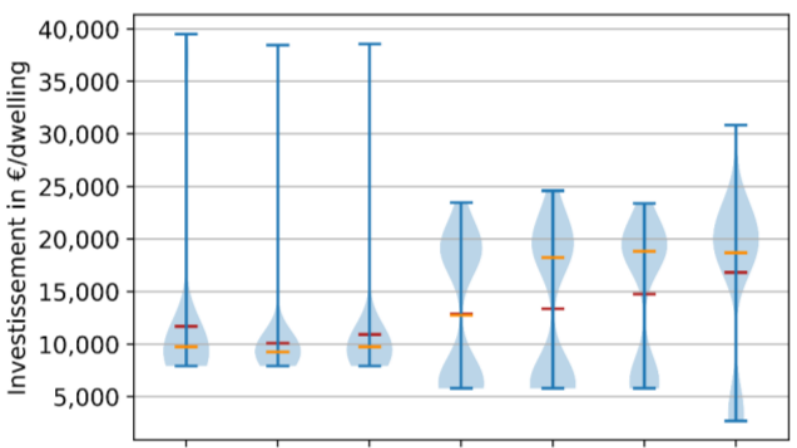

half $F$

Figure 12: Distribution of consumptions and investments per building for the alternative "full F" (left) and "half F" (right) The renovation actions that are performed for each building and each year are shown in Figure 13 using two graphs for each alternative. The share of renovation actions applied on each building at the end of the renovation process is plotted in the upper graphs (graphs A). In these graphs, one group of seven bars corresponds to a category of renovation action. For example, two shades of blue are used for actions on the ventilation: dark blue for SF and light blue for DF. In a group of seven bars, each bar represents one building of the virtual portfolio.

Regarding the façade renovation (gene 1), the tower was the most refurbished building before the apartment blocks of D2. Apartment blocks of D1 were less refurbished, especially in the "half F" alternative. In addition, apartment blocks with an E-W orientation were slightly more renovated than those having a N-S orientation, due to their higher energy consumption before refurbishment. Buildings of D2 were more frequently refurbished with a single-flow ventilation leading to an improvement of the energy performance at a lower cost. Two equivalent buildings such as the two apartment blocks of D2 can be refurbished differently within the optimisation process, explaining the 
different distributions, means and median values observed in Figure 12. For instance, one of these two building (B D2 E-W right) is more refurbished in the "half F" alternative but the refurbishment is more likely to be less efficient. For D1 buildings, which had a higher energy performance before renovation (class D), when a façade renovation was applied, the double-flow ventilation was preferred in order to significantly increase the performance. The minimal wall insulation level (CITE), that have a lower investment cost, was more frequently chosen, especially in "half F". However, higher insulation level such as RT2012 and to a lesser extent EnerPHit may be chosen to reach a higher energy performance. When buildings were refurbished, the preferred covering was plaster as this option is less expensive.

Regarding cavity renovation (gene 2), the same trends are observed than for gene 1 : buildings of D2 and buildings with an E-W orientation were more frequently refurbished. In addition, the tower was still the most frequently refurbished building. When the budget constraints are more severe, the share of apartment blocks renovated slightly decreases while the share of tower renovated increases, showing that the priority is given to this building in average. There is not clear trend regarding the insulation level to choose. However, when the constraints are strong, the insulation level EnerPHit is almost never used for buildings of D1.

Regarding loft insulation (gene 3), different trends are observed. Buildings of D1 were more frequently refurbished than buildings of D2. This can be explained by the difference in the roofs of buildings of D1 and of D2. While buildings of D1 have a flat roof insulation, the insulation of buildings of D2 is set on the floor of the unoccupied roof space. In addition, it is difficult to conclude regarding the choice of insulation level.

For the systems renovation (gene 4), the buildings should be connected to the district heating, which can be explained by the fact that this option leads to the lowest investment costs. 


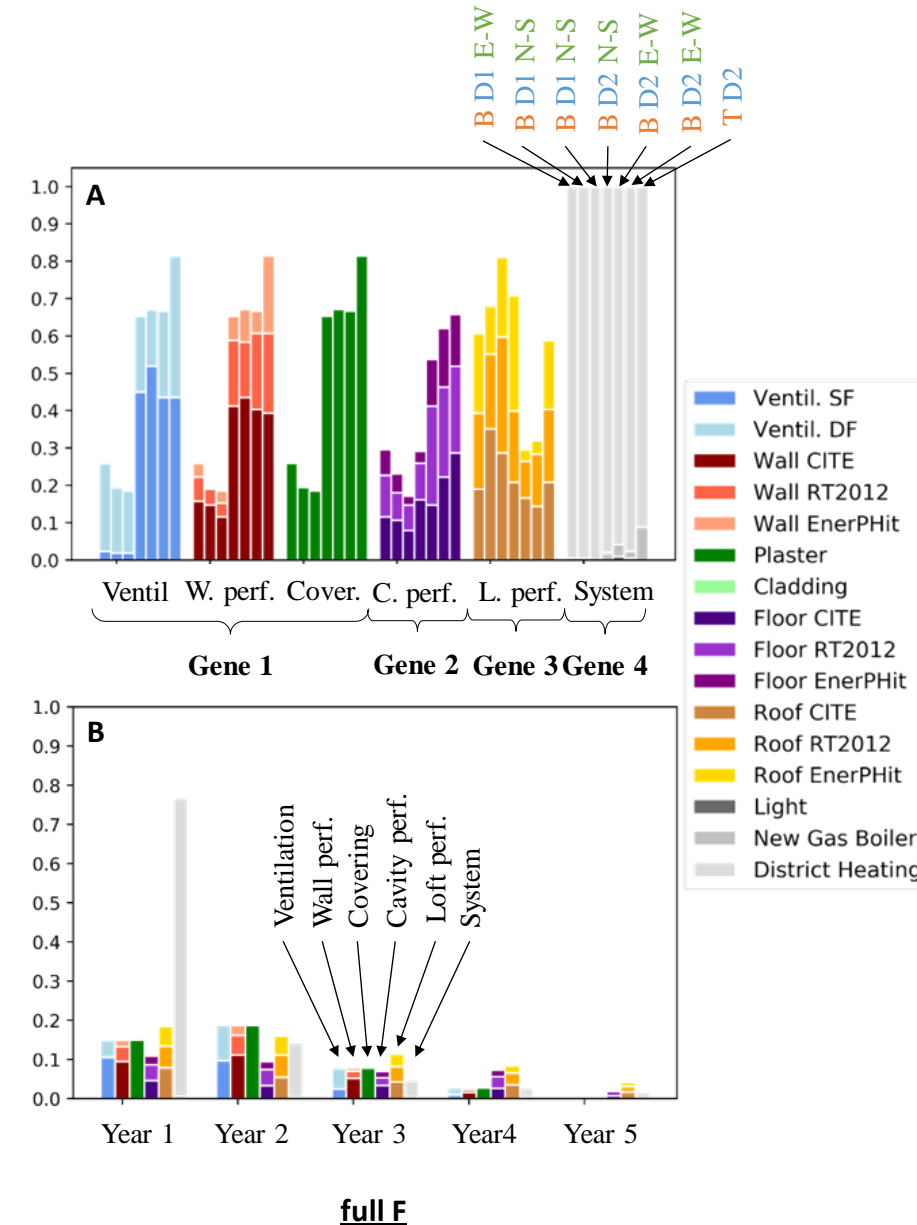

full F

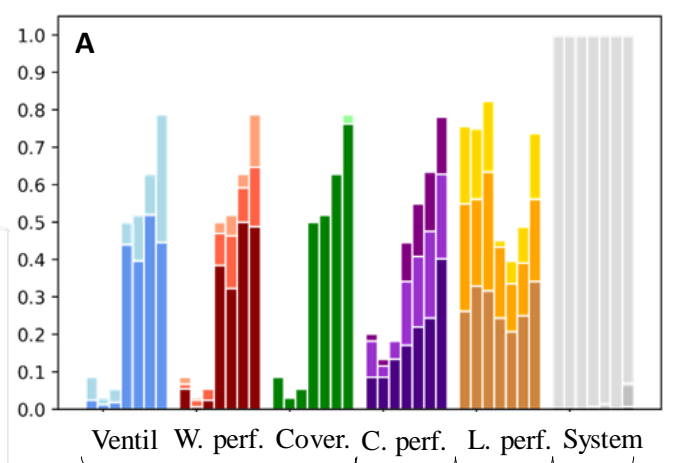

Gene 1

Gene 2 Gene 3 Gene 4

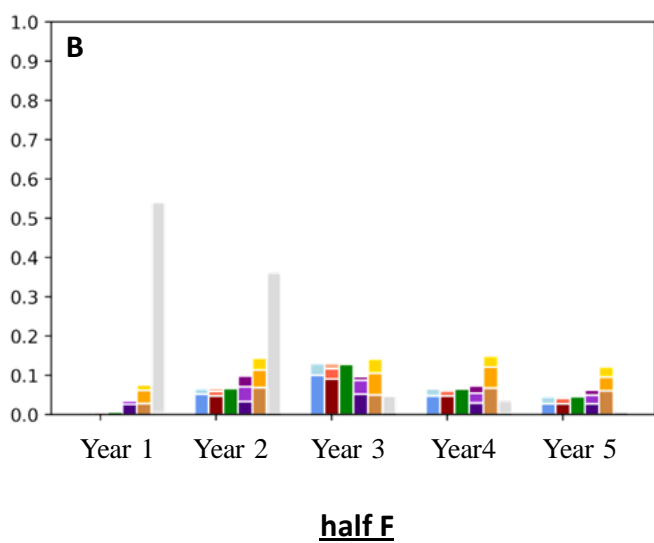

Figure 13: Characteristics of the optimal schedules for the alternative "full F" (graphs A and B left) and "half F" (graphs A and $B$ right). The $y$-axis gives the probability of renovation.

The share of renovation actions performed each year at the portfolio level is plotted in the lower graphs of Figure 13 (graphs B). In these graphs, one group of six bars corresponds to the actions conducted each year on all buildings of the virtual portfolio and one bar correspond a category of renovation action. When the budget constraints are lower (alternative "full F"), systems are refurbished from the first year. Other renovations are then planned over time and carried out as soon as budget is available: they are mainly performed during year 1,2 or 3 . When budget constraints are more severe ("half F"), renovation work is re-scheduled over the five years but the change of energy systems is still the priority: for almost all Pareto-optimal schedules, this action is done during the first or the second year. This result cannot be generalised: it corresponds to the very specific context of this case study where district heating is used, and subsidised by the company. Thus the cost of the third package of the system renovation only consists in the maintenance actions 
on the heating distribution network. In the case of a gas boiler, improving the envelope would probably be prioritised because otherwise a large boiler would first be installed, and the heating demand would eventually decrease, leading to a low load and a low efficiency. For next studies, it is thus recommended to improve the modelling of the boiler efficiency so that this parameter vary according to the boiler load rate.

Graphs of Figure 13 do not inform about the degree of urgency of performing one action on one building as the link between refurbished buildings and year of renovation is not plotted. In order to determine in which actions to invest in priority for one building, graphs of Figure 13 can be used. They are given for three buildings for the alternative "full F". In each graph, the characteristics of the Pareto-optimal schedules are scanned in the direction of an increased global investment. Members of the Pareto front are ranked from smallest to largest investment. For each investment, if a renovation is applied on façades, lofts, cavities or systems, a counter is incremented. The ordinate axis corresponds to the probability of performing a renovation on each of the four elements. For the apartment block of D1 with an E-W orientation (B D1 E-W), the first euros are invested for systems and loft renovation, while cavity insulation and to a larger extend façade renovation are less urgent. Thus such renovation actions are more likely to be performed after the first year. On the contrary, for the tower of D2 (T D2) all of four combined renovation actions are undertaken even if the investment is low, showing that all renovation actions are urgent for this building.
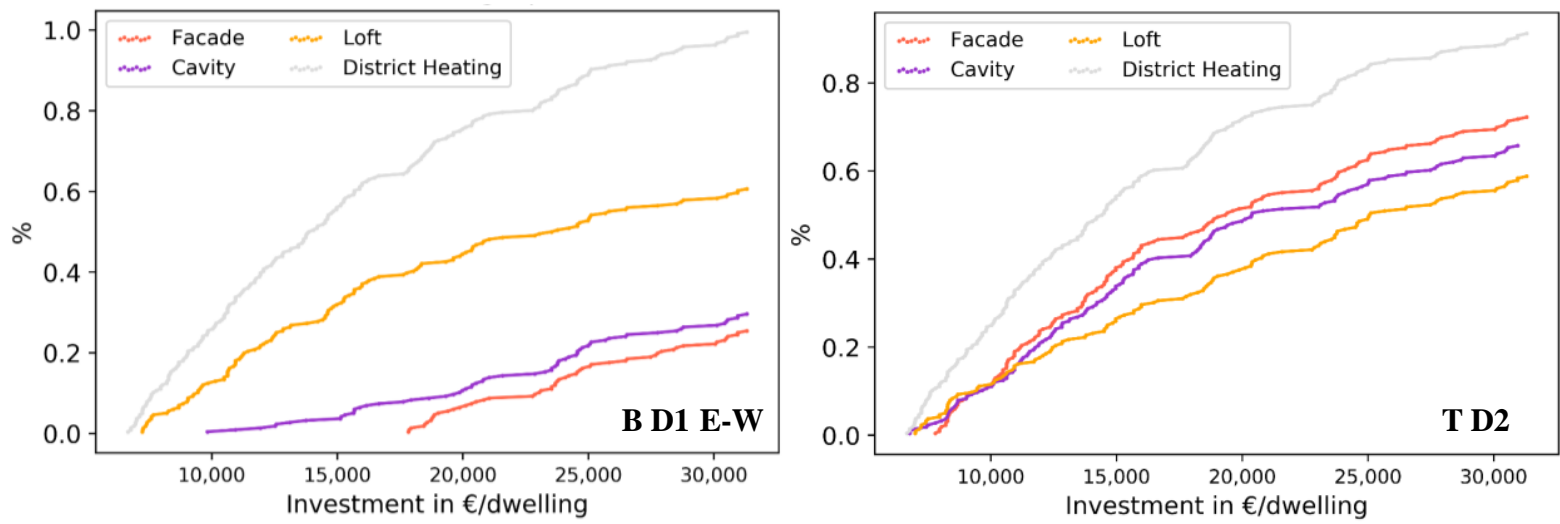

Figure 14: Order of renovation actions to perform for two buildings (B D1 E-W upper graph, T D2 graph below) for the alternative "full F" 


\section{Discussions and perspectives}

The application of the proposed methodology requires interactions between the portfolio property owner and a consultant familiar with energy simulation. The developed tool is intended to be used by the consultant who can advise facility managers based on the results obtained. This approach may differ from the methodology currently applied by facility managers who generally use easily managed tools that may lead to sub-optimal renovation strategies. More efficient renovation sequences, that meet budget constraints, can be identified in a limited computation time using the adapted optimisation algorithm.

In the case study, three representative buildings were chosen in order to model the virtual portfolio. The choice was based on expert judgement and on parameters describing the building state before refurbishment (morphology, energy class). However, choosing representative buildings on the basis of these criteria may be not sufficient nor justified as highlighted by Rivallain et al. [62]. In future work, a clustering approach, as used in Pistore et al. [24] or Rivallain et al. [62], will be investigated in order to identify representative buildings more appropriately and to improve the modelling. Furthermore, the case study could be extended in order to include buildings from other districts of the building portfolio. In this case, the same optimisation process can help identifying which district should be refurbished in priority, similarly to other studies using different methodologies $[23,31,32]$.

When renovations are applied to a building, they should lead to a significant decrease of energy consumptions. If it is not the case, the building will have a poor energy performance until the next renovation 20 or 25 years later. In addition, incomplete renovation will make further renovation less economical, e.g. increasing an insulation thickness from 6 to $12 \mathrm{~cm}$ is less favourable economically than from 0 to $12 \mathrm{~cm}$. In order to ensure that renovations are efficient, an a posteriori filtering of optimal solutions can currently be set up. However, the methodology could be extended to consider safeguards in terms of installed insulation thickness and of energy performance gain obtained 
through the renovation. By using such additional constraints poor renovation actions would be avoided.

In this study, the main focus was on energy consumption and investment cost. Although not shown in the present paper, the thermal comfort was also studied in order to ensure that the renovation did not cause overheating in summer. Assuming both natural ventilation at night (a flow rate of $10 \mathrm{vol} / \mathrm{h}$ was set when the indoor temperature exceeds $24{ }^{\circ} \mathrm{C}$ while the outdoor temperature remains below the indoor temperature) and the use of blinds on summer days ( $80 \%$ occultation on the windows), overheating was avoided. In the most energy efficient renovations, the temperature did not exceed $28^{\circ} \mathrm{C}$ for most buildings. In the worst case, for the N-S oriented apartment block of district $\mathrm{D} 2$, the indoor temperature exceeded $28^{\circ} \mathrm{C}$ during 35 hours per year, but remained below $31^{\circ} \mathrm{C}$, as shown in Table 6.

Table 6: Summer comfort in the 5 building morphologies with the most energy efficient renovations

\begin{tabular}{|c|c|c|c|}
\hline Building & $\begin{array}{c}\text { Number of hours above } \\
\mathbf{2 8} \mathbf{~}^{\circ} \mathbf{C}\end{array}$ & $\begin{array}{c}\text { Discomfort Degree Hour } \\
\text { (basis } \mathbf{2 8}\end{array}$ & $\begin{array}{c}\text { Maximal temperature in the hottest thermal } \\
\text { zone }\end{array}$ \\
\hline B D1 E-W & $0 \mathrm{~h}$ & $0 \mathrm{DH}$ & $27,7^{\circ} \mathrm{C}$ \\
\hline B D1 N-S & $12 \mathrm{~h}$ & $12 \mathrm{DH}$ & $28,7^{\circ} \mathrm{C}$ \\
\hline B D2 N-S & $35 \mathrm{~h}$ & $54 \mathrm{DH}$ & $30,7^{\circ} \mathrm{C}$ \\
\hline B D2 E-W & $0 \mathrm{~h}$ & $0 \mathrm{DH}$ & $27,6^{\circ} \mathrm{C}$ \\
\hline T D2 & $0 \mathrm{~h}$ & $0 \mathrm{DH}$ & $26,5^{\circ} \mathrm{C}$ \\
\hline
\end{tabular}

Regarding the results, some analysis, such as the analysis on the slope change, has showed that it is not as easy as expected to set priorities in the renovation actions. In fact, studying the ratio energy consumption over investment for each building is not sufficient as the research space is not continuous. Due to the budgetary yearly and global constraints, as well as the significant investments required for some groups of renovation actions (e.g. for the façade renovation described in gene 1), optimal renovation schedules are complex to identify.

The aim of this study was to identify the priorities in terms of renovation action to perform, type of building to refurbish and scheduling. Therefore, a set of Pareto-optimal schedules was analysed. However, the methodology presented in section 2 could be further extended using a MCDM method 
to find the renovation schedule that best matches the decision-maker's preferences among the optimal solutions. In order to meet the decision, not only energy performance and cost are of interest. Additional qualitative criteria should be assessed for each optimal solution such as aesthetic aspects [63] or social related aspects (attractiveness of the residential buildings, specific demands from tenants, ...), which are important for building owners. Delhomme et al. [64] proposed an interesting participatory decision support tool based on an abstract argumentation system, in which all decision-makers explain their arguments to choose the most appropriate set of criteria as well as the best schedule. Then their tool helps solving potential conflicts between arguments and prioritising alternatives.

\section{Conclusion}

This paper presents a literature analysis on the optimisation of the refurbishment of building stocks. Some gaps were identified regarding the set of renovation actions to perform, the chosen optimisation criteria, and the possibilities to answer the "which action", "which building" and "which year" questions in one optimisation step without weighting a priori the performance criteria. Consequently, a methodology is proposed to help portfolio property owners to set refurbishment priorities under multi-year funding constraints. The methodology is based on the NSGA-II optimisation algorithm with some adaptations. Two chromosomes and specific constraints management were implemented in order to help building owners to determine in which buildings and renovation actions to invest first, as well as how to plan renovations over time. Furthermore, we suggest assessing the building energy performance using a dynamic building energy performance tool. In the optimisation process, the performance of renovation schedules is gradually improved and the set of Pareto-optimal schedules at the last generation is statistically analysed. From this analysis, priorities are established in terms of type of action to perform, type of building to refurbish and time sequencing. The methodology was applied to a virtual social housing portfolio representative of a real one located in Greater Paris Area. Renovation actions were carried out on the envelopes and 
systems of the seven buildings of the virtual portfolio. Within NSGA-II algorithm, the investment cost and energy consumption of numerous five-year renovation schedules were assessed and compared. After 1,500 generations, the statistical analysis of Pareto-optimal solutions showed that the connection of buildings to the district heating should be done in the first year. This result is specific to our case study in which the connection to the district heating is free of charge. Then, the façade renovation of the buildings that had a higher energy consumption before renovation should be undertaken as soon as required budget is available. Despite the fact that the results are case-study dependent, the methodology can be applied to various buildings stocks refurbishment problems in order to find the best renovation schedules, provided that the definition of the optimisation problem and the input data are consistent with the specifics of the stock. In addition, we recommend further extending the proposed methodology with a clustering approach to identify representative buildings, using more advanced results visualisation techniques, and involving an MCDM method to find the best renovation schedule based on decision-maker's preferences.

\section{Acknowledgements}

This work was performed within the frame of the research project REHA-PARCS, granted by the French national research agency (ANR). This project focusses on building stock modelling, MOO and MCDM, in the context of building stock refurbishment. The authors would like to acknowledge the social housing portfolio property owner OPHM for providing data on their building stock. We are grateful to the building design engineering company OTEIS (previously ITF), which is part of the project, for their support regarding the definition of combination of renovation actions and for providing costs of renovation actions. We also would like to acknowledge the company Kocliko for their support in the development within the module Amapola of the software Pleiades.

\section{Bibliography}

[1] European Parliament, Directive 2012/27/EU of the European Parliament and of the Council of 25 October 2012 on energy efficiency, amending Directives 2009/125/EC and 2010/30/EU and 
repealing Directives 2004/8/EC and 2006/32/EC Text with EEA relevance, 2012. http://data.europa.eu/eli/dir/2012/27/oj/eng (accessed May 21, 2020).

[2] O. Lucon, D. Ürge-Vorsatz, A. Zain Ahmed, H. Akbari, P. Bertoldi, L. Cabeza, N. Eyre, A. Gadgil, D. Harvey, Y. Jiang, E. Liphoto, S. Mirasgedis, S. Murakami, J. Parikh, C. Pyke, V. Vilarino, Buildings, in: Climate Change 2014: Mitigation of Climate Change. Contribution of Working Group III to the Fifth Assessment Report of the Intergovernmental Panal on Climate Change [Edenhofer, O., R. Pichs-Madruga, Y. Sokona, E. Farahani, S. Kadner, K. Seyboth, A. Adler, I. Baum, S. Brunner, P. Eickemeier, B. Kriemann, J. Savolainen, S. Schlömer, C. von Stechow, T. Zwickel and J.C. Minx (Eds.)]., Cambridge University Press, Cambridge, UK and New York, NY, USA, 2014.

[3] Y. Saheb, Energy Transition of the EU Building Stock, Unleashingthe 4th Industrial Revolution in Europe, 2016. https://www.openexp.eu/sites/default/files/publication/files/energy_transition_of_the_eu_buil ding_stock_full_report.pdf.

[4] I. Costa-Carrapiço, R. Raslan, J.N. González, A systematic review of genetic algorithm-based multi-objective optimisation for building retrofitting strategies towards energy efficiency, Energy and Buildings. 210 (2020) 109690. https://doi.org/10.1016/j.enbuild.2019.109690.

[5] A.N. Nielsen, R.L. Jensen, T.S. Larsen, S.B. Nissen, Early stage decision support for sustainable building renovation - A review, Building and Environment. 103 (2016) 165-181. https://doi.org/10.1016/j.buildenv.2016.04.009.

[6] M. He, A. Brownlee, T. Lee, J. Wright, S. Taylor, Multi-objective Optimization for a Large Scale Retrofit Program for the Housing Stock in the North East of England, Energy Procedia. 78 (2015) 854-859. https://doi.org/10.1016/j.egypro.2015.11.007.

[7] Z. Wu, B. Wang, X. Xia, Large-scale building energy efficiency retrofit: Concept, model and control, Energy. 109 (2016) 456-465. https://doi.org/10.1016/j.energy.2016.04.124.

[8] R. Wu, G. Mavromatidis, K. Orehounig, J. Carmeliet, Multiobjective optimisation of energy systems and building envelope retrofit in a residential community, Applied Energy. 190 (2017) 634-649. https://doi.org/10.1016/j.apenergy.2016.12.161.

[9] L. Gabrielli, A.G. Ruggeri, Developing a model for energy retrofit in large building portfolios: Energy assessment, optimization and uncertainty, Energy and Buildings. 202 (2019) 109356. https://doi.org/10.1016/j.enbuild.2019.109356.

[10] Y. He, N. Liao, J. Bi, L. Guo, Investment decision-making optimization of energy efficiency retrofit measures in multiple buildings under financing budgetary restraint, Journal of Cleaner Production. 215 (2019) 1078-1094. https://doi.org/10.1016/j.jclepro.2019.01.119.

[11] G. Luddeni, M. Krarti, G. Pernigotto, A. Gasparella, An analysis methodology for large-scale deep energy retrofits of existing building stocks: Case study of the Italian office building, Sustainable Cities and Society. 41 (2018) 296-311. https://doi.org/10.1016/j.scs.2018.05.038.

[12] P. Murray, J. Marquant, M. Niffeler, G. Mavromatidis, K. Orehounig, Optimal transformation strategies for buildings, neighbourhoods and districts to reach $\mathrm{CO} 2$ emission reduction targets, Energy and Buildings. 207 (2020) 109569. https://doi.org/10.1016/j.enbuild.2019.109569.

[13] A. Rogeau, R. Girard, Y. Abdelouadoud, M. Thorel, G. Kariniotakis, Joint optimization of buildingenvelope and heating-system retrofits at territory scale to enhance decision-aiding, Applied Energy. 264 (2020) 114639. https://doi.org/10.1016/j.apenergy.2020.114639.

[14]S. Longo, F. Montana, E. Riva Sanseverino, A review on optimization and cost-optimal methodologies in low-energy buildings design and environmental considerations, Sustainable Cities and Society. 45 (2019) 87-104. https://doi.org/10.1016/j.scs.2018.11.027.

[15]F. Kheiri, A review on optimization methods applied in energy-efficient building geometry and envelope design, Renewable and Sustainable Energy Reviews. 92 (2018) 897-920. https://doi.org/10.1016/j.rser.2018.04.080.

[16] R. Evins, A review of computational optimisation methods applied to sustainable building design, Renewable and Sustainable Energy Reviews. 22 (2013) 230-245. https://doi.org/10.1016/j.rser.2013.02.004. 
[17] V. Machairas, A. Tsangrassoulis, K. Axarli, Algorithms for optimization of building design: A review, Renewable and Sustainable Energy Reviews. 31 (2014) 101-112. https://doi.org/10.1016/j.rser.2013.11.036.

[18] A.-T. Nguyen, S. Reiter, P. Rigo, A review on simulation-based optimization methods applied to building performance analysis, Applied Energy. 113 (2014) 1043-1058. https://doi.org/10.1016/j.apenergy.2013.08.061.

[19]T. Recht, P. Schalbart, B. Peuportier, Ecodesign of a "plus-energy" house using stochastic occupancy model, life-cycle assessment and multi-objective optimisation, in: Building Simulation \& Optimisation, Great North Museum, Newcastle, 2016: p. 8.

[20]S. Moghtadernejad, Luc.E. Chouinard, M.S. Mirza, Multi-criteria decision-making methods for preliminary design of sustainable facades, Journal of Building Engineering. 19 (2018) 181-190. https://doi.org/10.1016/j.jobe.2018.05.006.

[21] Ž. Morkūnaitè, D. Kalibatas, D. Kalibatienè, A bibliometric data analysis of multi-criteria decision making methods in heritage buildings, Journal of Civil Engineering and Management. 25 (2019) 76-99. https://doi.org/10.3846/jcem.2019.8315.

[22] F. Taillandier, L. Mora, D. Breysse, Decision support to choose renovation actions in order to reduce house energy consumption - An applied approach, Building and Environment. 109 (2016) 121-134. https://doi.org/10.1016/j.buildenv.2016.09.019.

[23] M. Österbring, C. Camarasa, C. Nägeli, L. Thuvander, H. Wallbaum, Prioritizing deep renovation for housing portfolios, Energy and Buildings. 202 (2019) 109361. https://doi.org/10.1016/j.enbuild.2019.109361.

[24] L. Pistore, G. Pernigotto, F. Cappelletti, A. Gasparella, P. Romagnoni, A stepwise approach integrating feature selection, regression techniques and cluster analysis to identify primary retrofit interventions on large stocks of buildings, Sustainable Cities and Society. 47 (2019) 101438. https://doi.org/10.1016/j.scs.2019.101438.

[25] G. Peri, G. Rizzo, G. Scaccianoce, V. Vaccaro, On the ranking criteria for energy retrofitting building stocks: Which building goes first? The role of the building size in the establishment of priority lists, Energy and Buildings. 150 (2017) 90-99. https://doi.org/10.1016/j.enbuild.2017.06.002.

[26] N. Heeren, M. Jakob, G. Martius, N. Gross, H. Wallbaum, A component based bottom-up building stock model for comprehensive environmental impact assessment and target control, Renewable and Sustainable Energy Reviews. 20 (2013) 45-56. https://doi.org/10.1016/j.rser.2012.11.064.

[27] L.G. Swan, V.I. Ugursal, Modeling of end-use energy consumption in the residential sector: A review of modeling techniques, Renewable and Sustainable Energy Reviews. 13 (2009) 18191835. https://doi.org/10.1016/j.rser.2008.09.033.

[28] M. Kavgic, A. Mavrogianni, D. Mumovic, A. Summerfield, Z. Stevanovic, M. Djurovic-Petrovic, A review of bottom-up building stock models for energy consumption in the residential sector, $\begin{array}{lllll}\text { Building and } 45 & \text { (2010) }\end{array}$ https://doi.org/10.1016/j.buildenv.2010.01.021.

[29] M. Brøgger, K.B. Wittchen, Estimating the energy-saving potential in national building stocks - A methodology review, Renewable and Sustainable Energy Reviews. 82 (2018) 1489-1496. https://doi.org/10.1016/j.rser.2017.05.239.

[30] C.A. Bana e Costa, R.C. Oliveira, Assigning priorities for maintenance, repair and refurbishment in managing a municipal housing stock, European Journal of Operational Research. 138 (2002) 380391. https://doi.org/10.1016/S0377-2217(01)00253-3.

[31] J. Keirstead, C. Calderon, Capturing spatial effects, technology interactions, and uncertainty in urban energy and carbon models: Retrofitting newcastle as a case-study, Energy Policy. 46 (2012) 253-267. https://doi.org/10.1016/j.enpol.2012.03.058.

[32] M. Jennings, D. Fisk, N. Shah, Modelling and optimization of retrofitting residential energy systems at the urban scale, Energy. 64 (2014) 220-233. https://doi.org/10.1016/j.energy.2013.10.076. 
[33] G.M. Mauro, M. Hamdy, G.P. Vanoli, N. Bianco, J.L.M. Hensen, A new methodology for investigating the cost-optimality of energy retrofitting a building category, Energy and Buildings. 107 (2015) 456-478. https://doi.org/10.1016/j.enbuild.2015.08.044.

[34] F. Taillandier, C. Fernandez, A. Ndiaye, Real Estate Property Maintenance Optimization Based on Multiobjective Multidimensional Knapsack Problem, Computer-Aided Civil and Infrastructure Engineering. 32 (2017) 227-251. https://doi.org/10.1111/mice.12246.

[35]S. Soutullo, E. Giancola, M.R. Heras, Dynamic energy assessment to analyze different refurbishment strategies of existing dwellings placed in Madrid, Energy. 152 (2018) 1011-1023. https://doi.org/10.1016/j.energy.2018.02.017.

[36] A. Carbonari, A. Corneli, G.M.D. Giuda, L. Ridolfi, V. Villa, A decision support system for multicriteria assessment of large building stocks, Journal of Civil Engineering and Management. 25 (2019) 477-494. https://doi.org/10.3846/jcem.2019.9872.

[37] M.Á. García-Fuentes, S. Álvarez, V. Serna, M. Pousse, A. Meiss, Integration of Prioritisation Criteria in the Design of Energy Efficient Retrofitting Projects at District Scale: A Case Study, Sustainability. 11 (2019) 3861. https://doi.org/10.3390/su11143861.

[38] C. Nägeli, A. Farahani, M. Österbring, J.-O. Dalenbäck, H. Wallbaum, A service-life cycle approach to maintenance and energy retrofit planning for building portfolios, Building and Environment. 160 (2019) 106212. https://doi.org/10.1016/j.buildenv.2019.106212.

[39] A. Farahani, H. Wallbaum, J.-O. Dalenbäck, Optimized maintenance and renovation scheduling in multifamily buildings - a systematic approach based on condition state and life cycle cost of building components, Construction Management and Economics. 37 (2019) 139-155. https://doi.org/10.1080/01446193.2018.1512750.

[40] M. Christen, B.T. Adey, H. Wallbaum, On the usefulness of a cost-performance indicator curve at the strategic level for consideration of energy efficiency measures for building portfolios, Energy and Buildings. 119 (2016) 267-282. https://doi.org/10.1016/j.enbuild.2016.02.056.

[41] K. Deb, A. Pratap, S. Agarwal, T. Meyarivan, A fast and elitist multiobjective genetic algorithm: NSGA-II, IEEE Transactions on Evolutionary Computation. 6 (2002) 182-197.

[42] J. Kennedy, R. Eberhart, Particle swarm optimization, in: Proceedings of ICNN'95 - International Conference on Neural Networks, 1995: pp. 1942-1948 vol.4. https://doi.org/10.1109/ICNN.1995.488968.

[43] C. a. B.E. Costa, J.-C. Vansnick, Applications of the MACBETH Approach in the Framework of an Additive Aggregation Model, Journal of Multi-Criteria Decision Analysis. 6 (1997) 107-114. https://doi.org/10.1002/(SICl)1099-1360(199703)6:2<107::AID-MCDA147>3.0.CO;2-1.

[44]T.L. Saaty, How to make a decision: The analytic hierarchy process, European Journal of Operational Research. 48 (1990) 9-26. https://doi.org/10.1016/0377-2217(90)90057-I.

[45] E. Van de Moortel, F. Troyer de, K. Allacker, L. Stijnen, E. Schoofs, Avoiding financial lock-in effects in case of a stepwise energy renovation of social housing in Flanders, in: 3rd International Conference on Energy, Environment and Economics, ICEEE2018, Edinburgh, UK, 2018. http://weentechpublishers.com/download.ashx?pid=8c5ee702-b01d-464c-ac88-55cf825e5570.

[46] B. Peuportier, I. Blanc-Sommereux, Simulation tool with its expert interface for the thermal design of multizone buildings, Int. J. of Solar Energy. 8 (1990) 109--120. https://doi.org/10.1080/01425919008909714.

[47] B. Peuportier, COMFIE, logiciel pour l'architecture bioclimatique, quelques applications pour les vérandas, in: Journée Technique GENEC (CEA), Cadarache, 1993, 1993.

[48] F. Munaretto, T. Recht, P. Schalbart, B. Peuportier, Empirical validation of different internal superficial heat transfer models on a full-scale passive house, Journal of Building Performance Simulation. 0 (2017) 1-22. https://doi.org/10.1080/19401493.2017.1331376.

[49] J.-P. Brasselet, J.-P. Domblides, D. Marchio, Banc d'essais comparatif de progiciels de calculs de charges hygrothermiques, AICVF-AITF-ARMINES, 1993.

[50] R. Judkoff, J. Neymark, International Energy Agency Building Energy SimulationTest (BESTEST) and Diagnostic Method. http://www. nrel.gov/docs/legosti/old/6231.pdf, National Renewable Energy Laboratory, Golden, CO, 1995. 
[51] B. Peuportier, Bancs d'essais de logiciels de simulation thermique, in: Journée Thématique SFTIBPSA, La Rochelle, 2005: p. 8. http://perso.univ-Ir.fr/fcherqui/IBPSAmars/textes/PM-04Peuportier.pdf.

[52] A. Brun, C. Spitz, E. Wurtz, L. Mora, Behavioural comparison of some predictive tools used in a low-energy building, in: Eleventh International IBPSA Conference, Glasgow, Scotland, 27-30 July 2009, 2009: pp. 27-30.

[53] M. Rivallain, P.E. Leger, O. Baverel, B. Peuportier, Decision aiding \& multi criteria optimization for existing buildings holistic retrofit, in: Vienna, Austria, 2012: pp. 1084-1092. https://hal-minesparistech.archives-ouvertes.fr/hal-00769827.

[54] M. Rivallain, O. Baverel, B. Peuportier, Genetic multi criteria optimization for existing buildings holistic retrofit, in: Nantes, France, 2012.

[55]Météo France, Le climat en France métropolitaine | Météo-France, (2020). https://meteofrance.com/comprendre-climat/france/le-climat-en-france-metropolitaine.

[56] République française, Arrêté du 26 octobre 2010 relatif aux caractéristiques thermiques et aux exigences de performance énergétique des bâtiments nouveaux et des parties nouvelles de bâtiments, 2010. https://www.legifrance.gouv.fr/eli/arrete/2010/10/26/DEVU1026270A/jo/texte.

[57] République française, Arrêté du 28 décembre 2012 relatif aux caractéristiques thermiques et aux exigences de performance énergétique des bâtiments nouveaux et des parties nouvelles de bâtiments autres que ceux concernés par l'article 2 du décret du 26 octobre 2010 relatif aux caractéristiques thermiques et à la performance énergétique des constructions, 2012. https://www.legifrance.gouv.fr/eli/arrete/2012/12/28/ETLL1233337A/jo/texte.

[58] J. Knowles, D. Corne, On metrics for comparing nondominated sets, in: Proceedings of the 2002 Congress on Evolutionary Computation. CEC'02 (Cat. No.02TH8600), 2002: pp. 711-716 vol.1. https://doi.org/10.1109/CEC.2002.1007013.

[59]T. Recht, Étude de l'écoconception de maisons à énergie positive, Thèse de doctorat, École nationale supérieure des mines de Paris, 2016. https://www.theses.fr/2016PSLEM024.

[60] M.-L. Pannier, T. Recht, M. Robillart, B. Peuportier, L. Mora, Élaboration de séquences de rénovation optimales pour un parc de bâtiments (Submitted), in: IBPSA France, Reims, France, 2020:

p.

8 , http://www.ibpsa.fr/jdownloads/Conferences_et_Congres/IBPSA_France/2020_conferencelBPS A/pannier-1142-1142.pdf .

[61] Union sociale pour l'habitat, "La rénovation énergétique des logements sociaux dans 6 pays européens" in Actualité Habitat $\mathrm{n}^{\circ} 1078$, L'Union sociale pour l'habitat. (2018). https://www.union-habitat.org/actualites/la-renovation-energetique-des-logements-sociauxdans-6-pays-europeens (accessed May 16, 2021).

[62] M. Rivallain, S. Agapoff, P. Boisson, A. Foucquier, Y. Lee, Clustering As A Simplification Tool For The Decision-Making Process On Building Stock Renovation, in: BS 2019, Rome, 2019: p. 8.

[63]M. Sunikka-Blank, R. Galvin, Irrational homeowners? How aesthetics and heritage values influence thermal retrofit decisions in the United Kingdom, Energy Research \& Social Science. 11 (2016) 97-108. https://doi.org/10.1016/j.erss.2015.09.004.

[64] B. Delhomme, L. Mora, F. Taillandier, Un outil participatif d'aide à la décision appuyé par un système d'argumentation pour la réhabilitation thermique d'un parc de bâtiments, in: IBPSA France $2018 \quad$ Bordeaux, $2018: \quad$ p. https://www.researchgate.net/publication/327884136_Un_outil_participatif_d'aide_a_la_decisi on_appuye_par_un_systeme_d'argumentation_pour_la_rehabilitation_thermique_d'un_parc_d e_batiments. 